\title{
Memorie tecniche e ricordi familiari. Torino e Reggio Calabria nelle carte e nei disegni dell'archivio Porcheddu
}

\author{
Giuseppa Novello
}

Abstract

Commenti critici di sintesi, immagini composte da disegni e altre elaborazioni accompagnano attraverso mutui rimandi gli esiti della ricerca condotta sul patrimonio documentale contenuto nell'archivio torinese della Società G. A. Porcheddu, con riguardo agli interventi dell'impresa condotti a Reggio Calabria e provincia, tra il 191 I e il 1923. L'analisi degli originari propositi architettonici e le risposte offerte dalle soluzioni delineate per l'impianto statico-strutturale sono stati campo di indagine privilegiato per riflettere sul sistema di lavoro che consenti di vincere la sfida pressante della ricostruzione post sismica. Sfida che i materiali di archivio, indagati attraverso metodi comparativi interessati alle istanze derivanti dai due ambienti di elaborazione, dimostrano che fu affrontata adottando modalità di lavoro altamente collaborative. Le considerazioni percorrono un itinerario che coinvolge realizzazioni di differente importanza e concezione, accogliendo la tensione conoscitiva intrinsecamente connessa con alcune forme espressive del disegno attivate anche per gestire con coerenza progettuale la complessità operativa pretesa dalla criticità del momento. Piace pensare che i documenti oltre a rappresentare un tramite per ricomporre il sistema delle tante relazioni intercorse tra committenza, professionisti, maestranze, hanno fondato un'alleanza vincente tra Torino e Reggio, sodalizio che, malgrado la distanza geografica che intercorre tra le due città, emerge dal passato e continuamente si rinnova.

Parole chiave

archivio Porcheddu, Reggio Calabria, concezioni strutturali e architettoniche, disegno di progetto, costruzioni antisismiche.

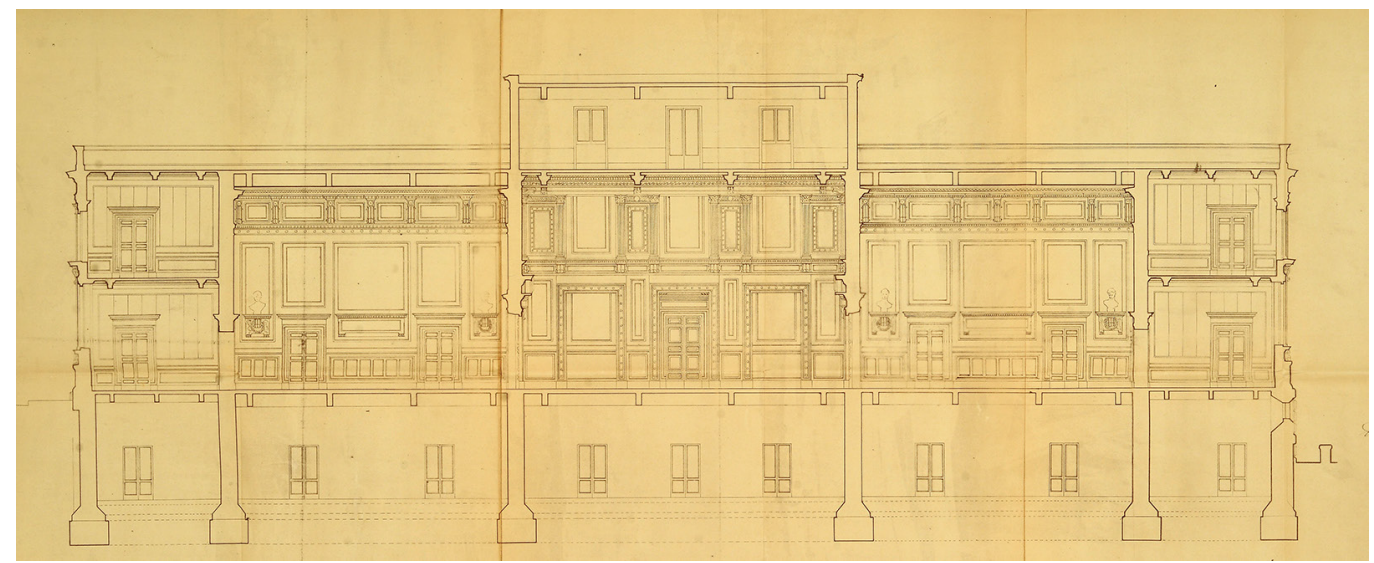


Alcune vicende storiche dell'ingegneria italiana dei primi decenni del 1900 creano una connessione diretta tra Torino e Reggio Calabria, tra le memorie tecniche si aprono spiragli di ricordi familiari, questo contributo ne vorrebbe evocare le vaghe corrispondenze.

Aderendo all'invito esplicito di oltrepassare il "semplice pensiero razionale" espresso nelle parole di introduzione scelte dagli organizzatori di questo quarantaduesimo convegno UID ho pensato di proporre alcune riflessioni sul rapporto che si è instaurato tra propositi architettonici e risposte tecnologico-costruttive derivanti da istanze ambientali severe e ineludibili quali sono quelle date dal contesto geologico e geodinamico dell'area che include Reggio e Messina; in realtà tra le parole e le immagini di questo contributo un filo rosso colleziona una serie di trame più o meno palesi che mi auguro possano essere percorse per discuterne. Un'analogia di relazioni che si ispira al complesso intreccio interpretativo che richiama da una parte il mito di Prometeo, il titano incatenato da Zeus per aver donato all'umanità il fuoco, e dall'altro quello di Mnemosine, depositaria della memoria e madre delle Muse; un incontro invocato per fornire filtri di lettura molteplici, sguardi per legare intenzioni ed esiti dell'azione di ricerca svolta, seguendo l'auspicio che attraverso questa mia rappresentazione, necessariamente sintetica, "Si potranno tracciare infinite storie che si dissimulano nelle parole, che generano figure, che hanno insondabili profondità semantiche".

\section{Riferimenti di contesto e fonti}

Tutto comincia quando ho deciso di approfondire precedenti spunti di indagine orientati ad esplorare alcune forme espressive del disegno, attinenti all'ambito esecutivo e costruttivo, qualificate da una tensione conoscitiva che collega con inscindibili nessi architettura e struttura. Come altrove annotato [Novello et al. 20 I7] parlando delle sperimentazioni grafiche adottate nella rappresentazione del calcestruzzo armato, nei primi decenni della sua introduzione, preme ribadire che: "con riguardo a tutto il processo di elaborazione, dal momento ideativo a quello costruttivo, le indagini sul disegno e sulla rappresentazione risultano particolarmente stimolanti se si ha cura di concentrare la ricerca sui primi empirici adattamenti promossi all'interno delle relative prassi progettuali e produttive". Gli esiti di quelle investigazioni avevano portato a sottolineare che: "Per concezioni nuove servono nuovi disegni, perché è indubbio che nel momento in cui si produce il disegno per l'innovazione deve percorrere strade fino a quel momento non battute, sostituendo o affiancando alle tradizionali forme, consolidate da un uso divenuto pratica condivisa e nota, altre invenzioni espressive" [I].

Ho inteso continuare quelle prime esplorazioni, condotte allora in compagnia di giovani amici, restringendo l'ambito di indagine per dedicarlo a un posto che sta nel mio cuore.

Per ritrovarmi a Reggio ho percorso con maggiore cura i territori e gli scenari di un archivio che parla di architetture reggine e che mi ha consegnato nuove emozioni.

Tra le carte e i disegni custoditi nell'Archivio della Società Giovanni Antonio Porcheddu, sono conservati alcuni documenti che riguardano una serie di progetti e lavori realizzati dall'impresa torinese in Calabria e in Sicilia, ascrivibili per lo più a quel periodo di vivace fermento progettuale e costruttivo conseguente agli interventi avviati dopo il terremoto che nel 1908 colpì così rovinosamente Reggio e Messina. Tra i dodici comparti territoriali che segnano l'originaria classificazione [2] adottata dalla società per conservare la documentazione del proprio operato dal 1895 al 1933 , undici faldoni fanno riferimento alle attività dell'impresa condotte tra Messina e Palermo e otto ai lavori inerenti a diciotto opere localizzate nella città di Reggio e cinque nel suo territorio provinciale. Le circa duemilaseicento pratiche che raccolgono tutti gli interventi cui lavorò la Società sono numerate in ordine crescente all'interno di cartelline distinte, collezionate in trecento ottantacinque faldoni; 
suddivise per località e anno offrono un repertorio molto vario di dati documentali, tanto che esaminandone l'articolazione ricorrente è possibile tracciare un quadro abbastanza dettagliato dell'organizzazione dell'impresa e delle relative modalità operative. Carte e disegni intessono una trama composita, variegata nella consistenza secondo l'importanza dei lavori riferibili alle singole pratiche, ma un ordinato sistema di archiviazione (mai casuale, tanto da prevedere una modulistica appositamente stampata per i diversi settori di attività, già in fase di redazione), si prende carico di collezionare i materiali riunendoli in tipologie di documentazione, seguendo un metodo che adotta criteri di suddivisione utili per la gestione del complesso delle attività svolte. Un'operazione sistematica necessaria per tenere
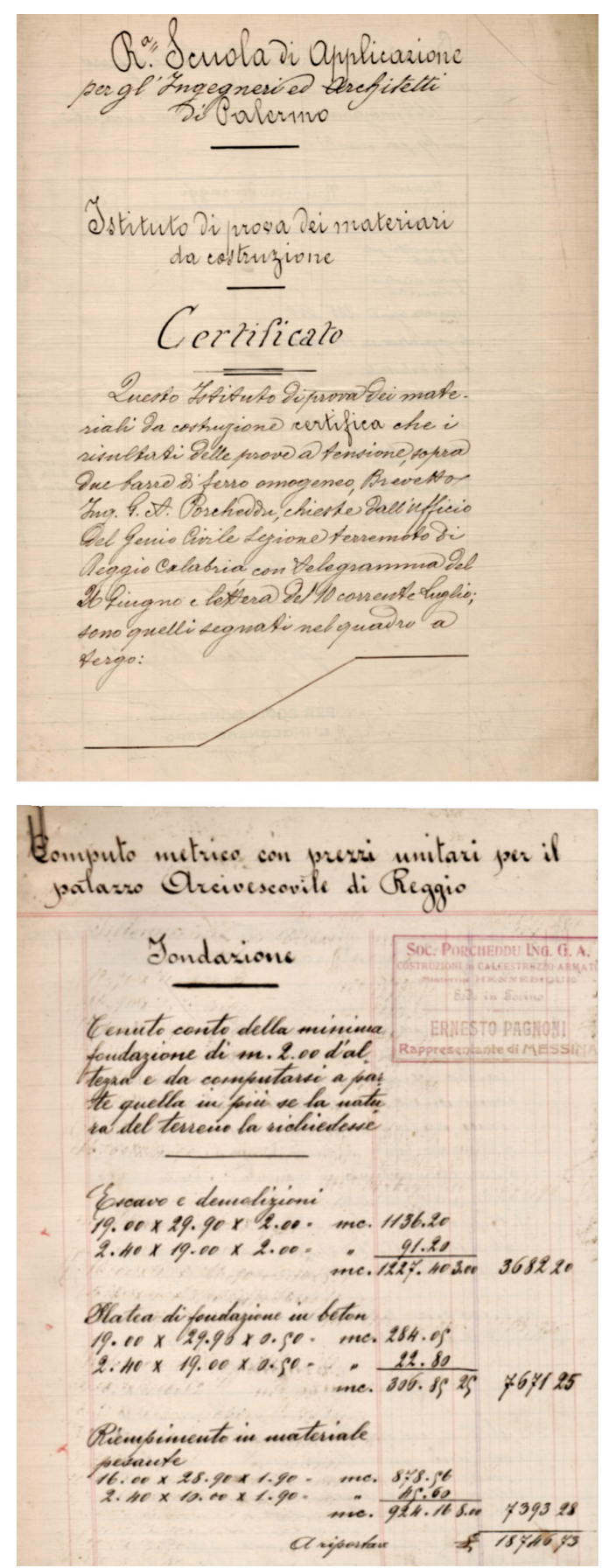
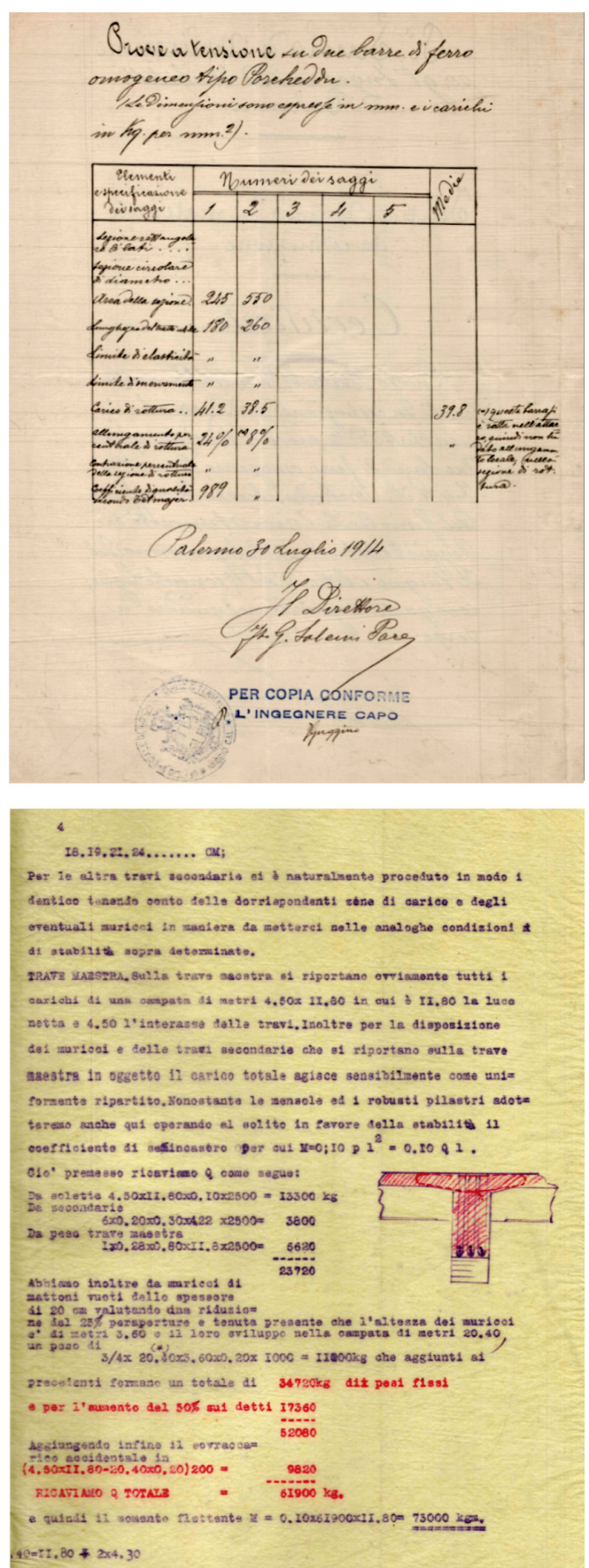

Fig. I. Certificato di prova su due barre di ferro "Porcheddu", Laboratorio Università di Palermo (sopra). Computo metrico estimativo (palazzo Arcivescovile) e pagina di prima relazione di calcolo (sotto). 

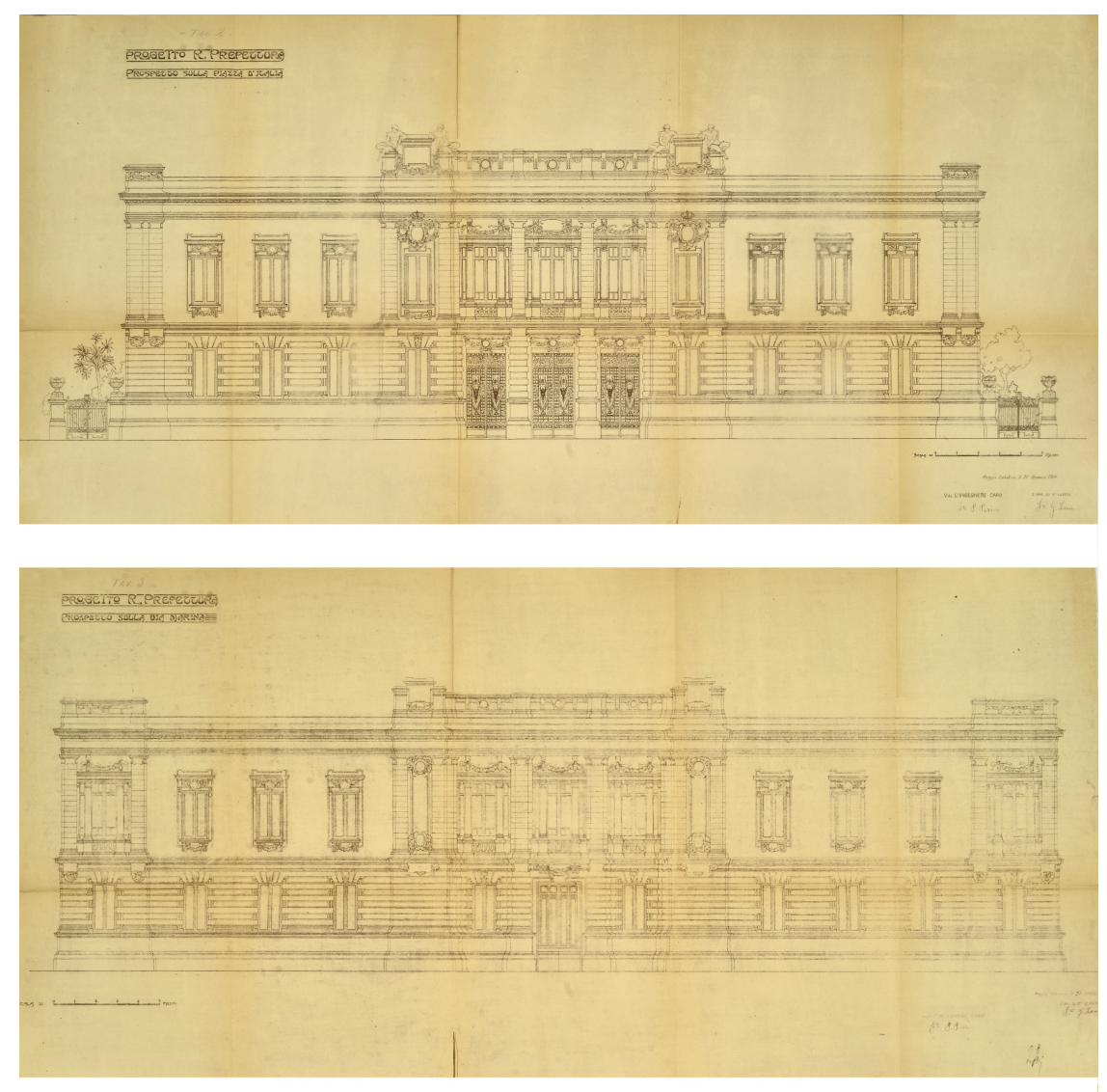

Fig. 2. Regia Prefettura

classe Zani siglano le

tavole inviate all'impresa

Porcheddu per la

definizione del sistema

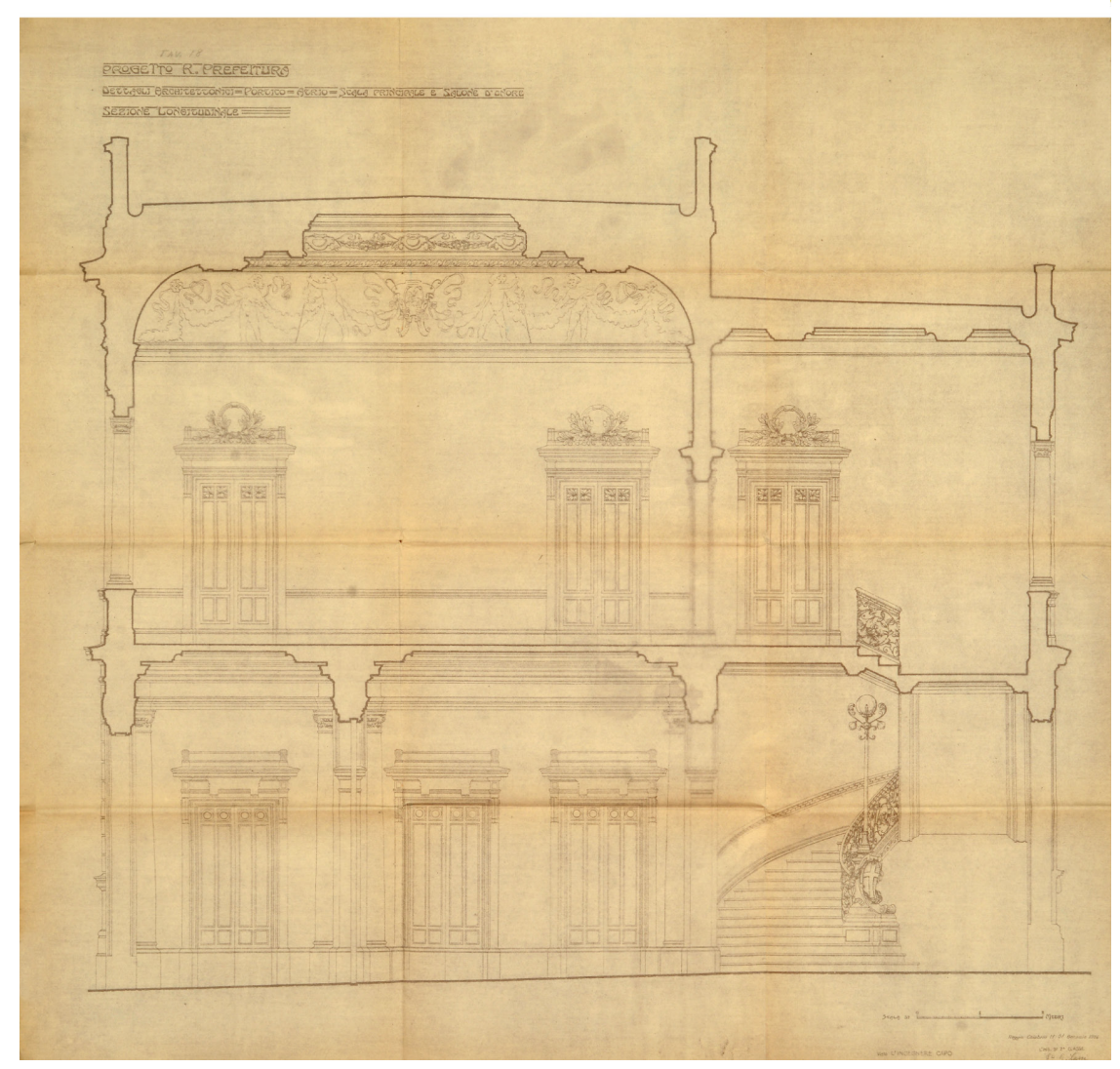


sotto controllo tempi e metodi di lavoro, e poter verificare impegni e risorse, perseguendo un costante monitoraggio che si prolunga per tutta la durata del processo esecutivo anche quando inevitabili imprevisti ne hanno interrotto il naturale svolgimento, come avvenne in parte durante gli anni della Prima Guerra Mondiale. Questa sistematicità, perseguita in origine anche per poter operare contemporaneamente in diversi luoghi e far fronte a differenti tipologie di intervento, diviene prerogativa che rende oggi possibile rielaborare le informazioni contenute in quanto conservato, consentendo di formulare ipotesi e offrendo molteplici chiavi di lettura inedite.

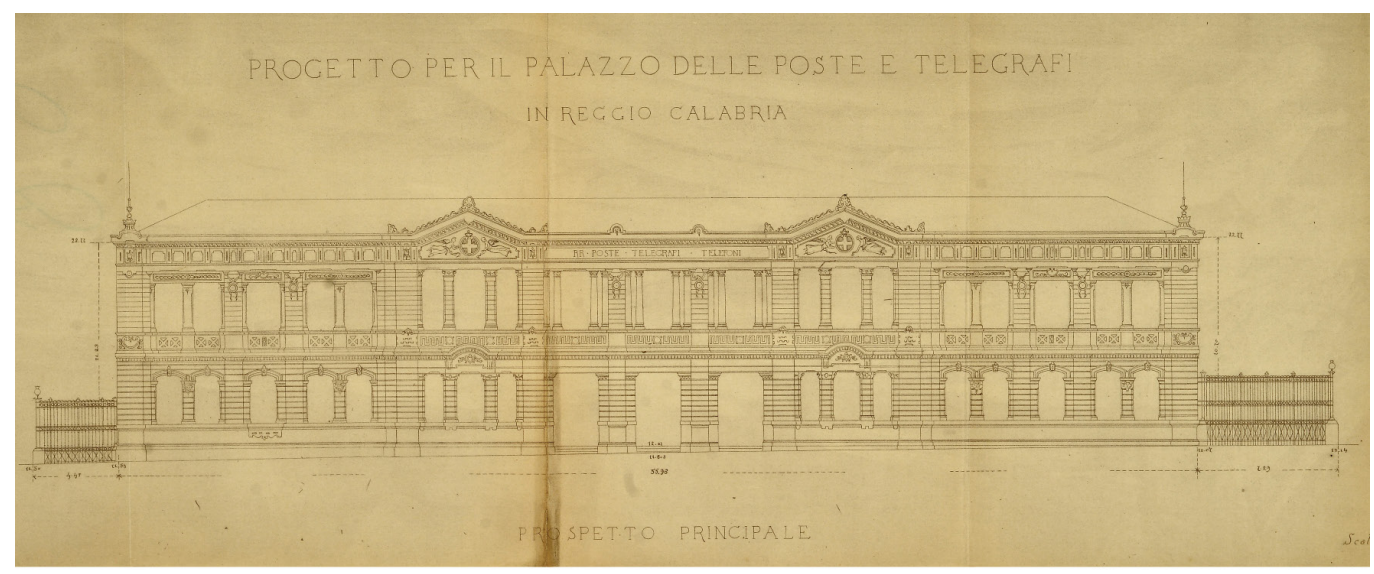

Fig. 3. Palazzo Poste e Telegrafi $(4658 / 7)$. I disegni architettonici nei prospetti originali celebrano il valore

scenografico assegnato alle architetture della

ricostruzione: Prospetto

Principale, sulla via Nuova Terme e fianco sulla via Prefettura.
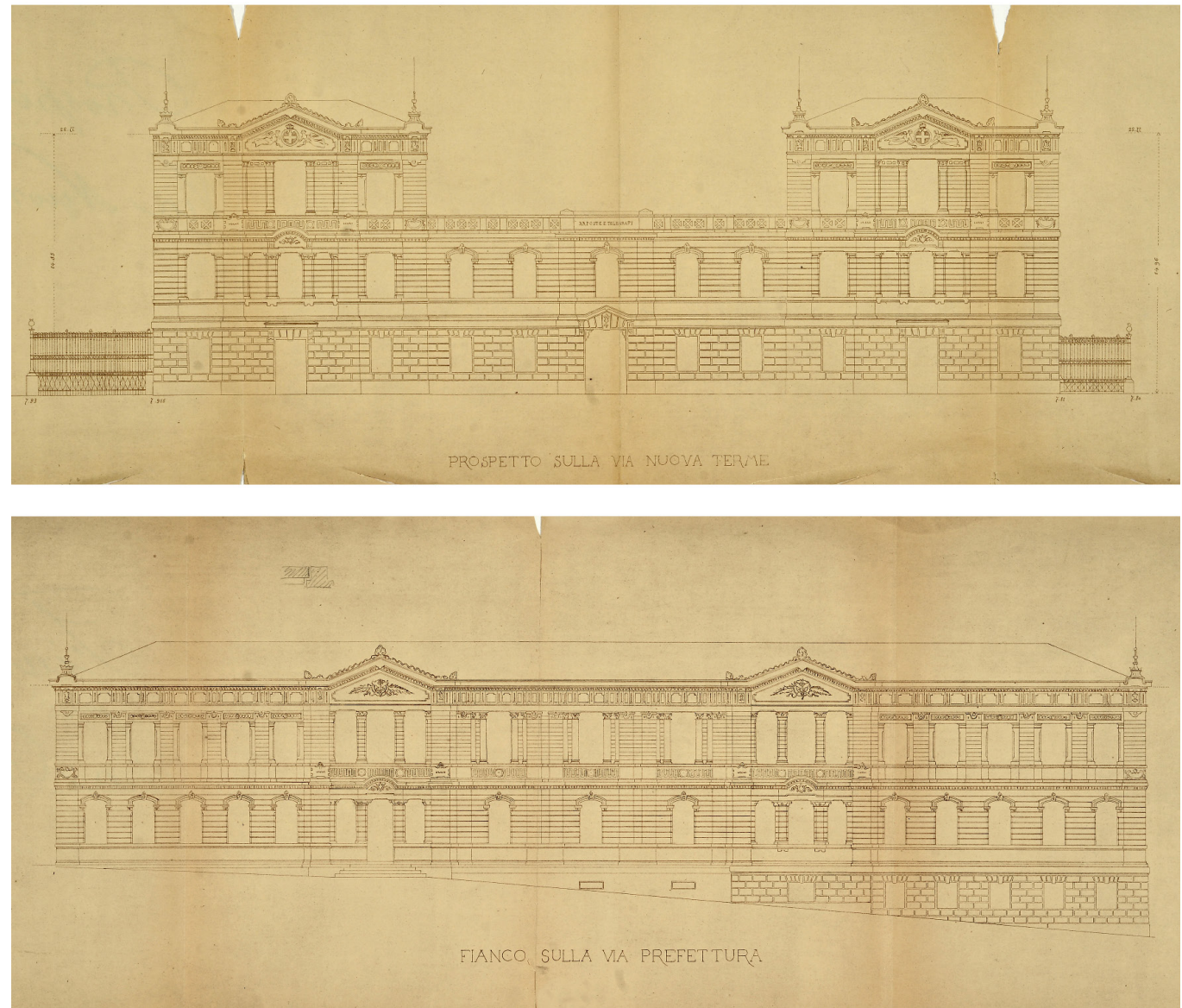
Si tratta di collegare tra loro documenti che, in modo diretto o indiretto, rinnovano il loro potenziale informativo e sono capaci di restituire memoria e testimonianza di una fitta serie di nessi che permettono, oggi, di conoscere o intuire molte cose: le relazioni tenute con i diversi committenti pubblici e privati, il flusso di lavoro interno e quello che intercorreva tra casa madre torinese e i professionisti che ne erano i rappresentanti locali (ingegneri Pagnoni, Traverso e Rossi), le elaborazioni tecniche preliminari e definitive, le alternative di calcolo strutturale ed economico scartate e quelle scelte, i contratti di appalto o di fornitura e le relative criticità, i memoriali relativi ad alcune immancabili protratte controversie, i rapporti tenuti con i progettisti autori delle ideazioni architettoniche e distributive di grandi e piccoli interventi (fig. I). Un insieme di tracce che rendono evidente metodo ed efficienza operativa in un'epoca (191 |-1923, se si pensa agli interventi realizzati tra Reggio e provincia) nella quale i sistemi di comunicazione tra nord e meridione erano indubbiamente difficili tanto per le persone quanto per gli approvvigionamenti e il trasporto dei materiali necessari per l'opera di costruzione.
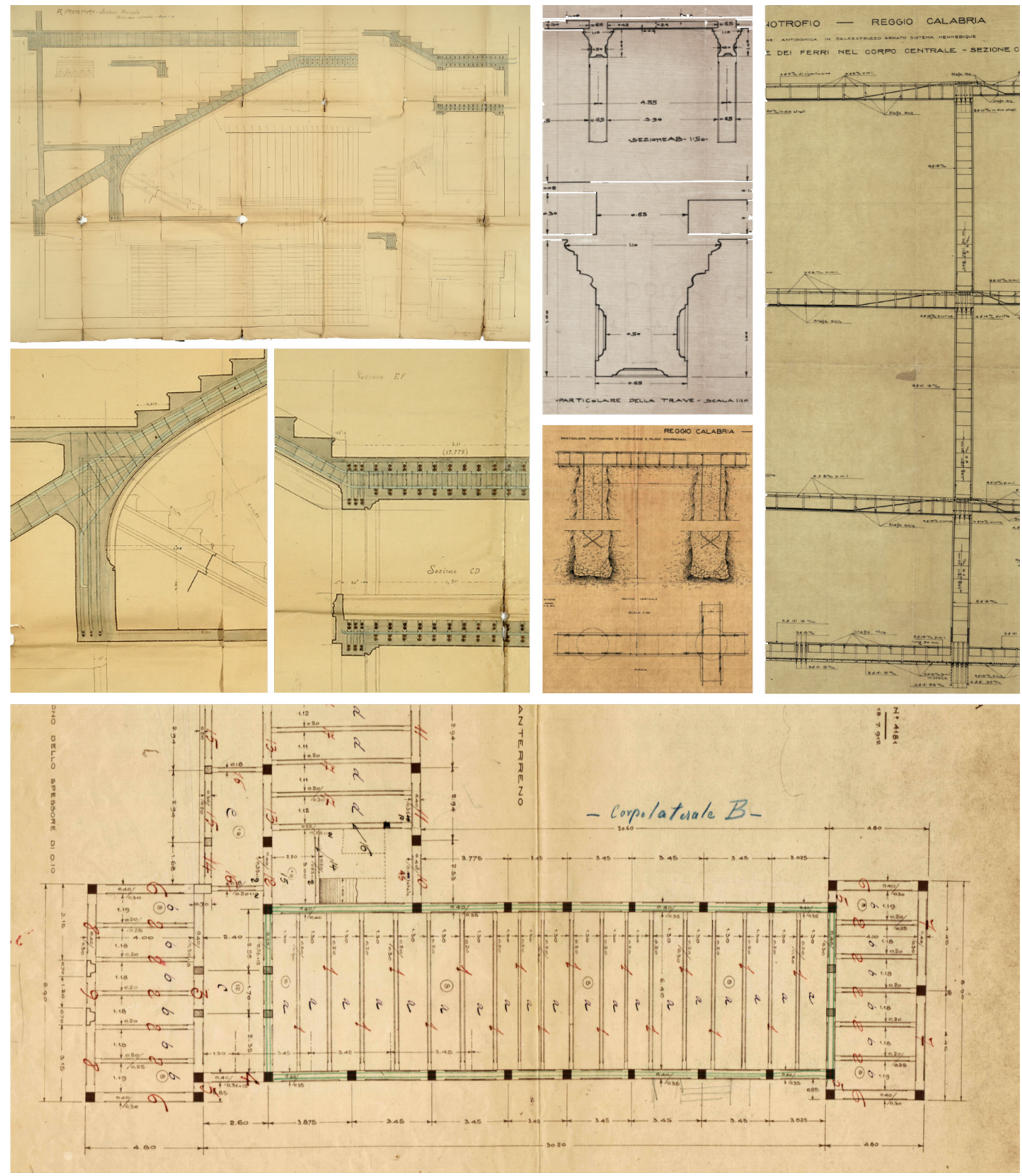

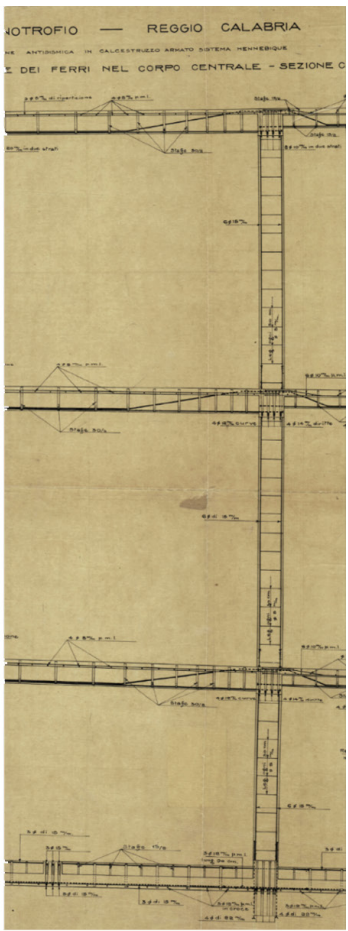

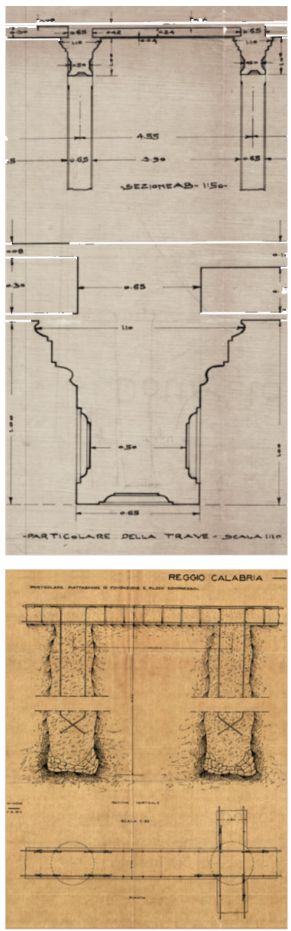

Fig. 4. Dentro le sagome dei volumi di ingombro l'articolazione strutturale tesse trame resistenti invisibili. Scalone Prefettura (5270/4) Sagome travi e fondazion a pali Poste e Telegrafi travi e solai Orfano dirofio (4I8I/I). 


\section{Motivazioni per continuare a sfogliare disegni e carte}

La lunga esperienza di consultazione dell'archivio mi ha facilitato in questa seconda fase di esplorazione, che ho condotto con piacere rinnovato perché il ricco patrimonio di disegni inerenti ai lavori prodotti per Reggio Calabria è qualificato da alcuni peculiari attributi di grande interesse, proprio in relazione alla stretta alleanza che si è attuata tra la tensione statico-strutturale invocata e verificata dalle direttive antisismiche concepite per la ricostruzione dagli ingegneri [3] e le soluzioni di ordine architettonico compositivo progettate dagli architetti. Una progettazione che ha interessato molti edifici delle istituzioni e dei servizi cittadini, capisaldi di una identità urbana segnata profondamente dal trauma del terremoto del 1908, la cui ricomposizione è frutto del piano regolatore di Pietro De Nava [4], che ha fortemente cambiato l'immagine ambientale del capoluogo attraverso una serie di interventi edificatori sensibilmente coordinati, emergenti in un paesaggio più ampio che, attraverso accortezze panoramiche, si proietta e comprende la distesa del mare e la costa siciliana. La stessa immagine richiamata dai miei primi ricordi, quella di una scenografia urbana elegante, composta e luminosa, percezione impressa nella mia memoria da sempre.
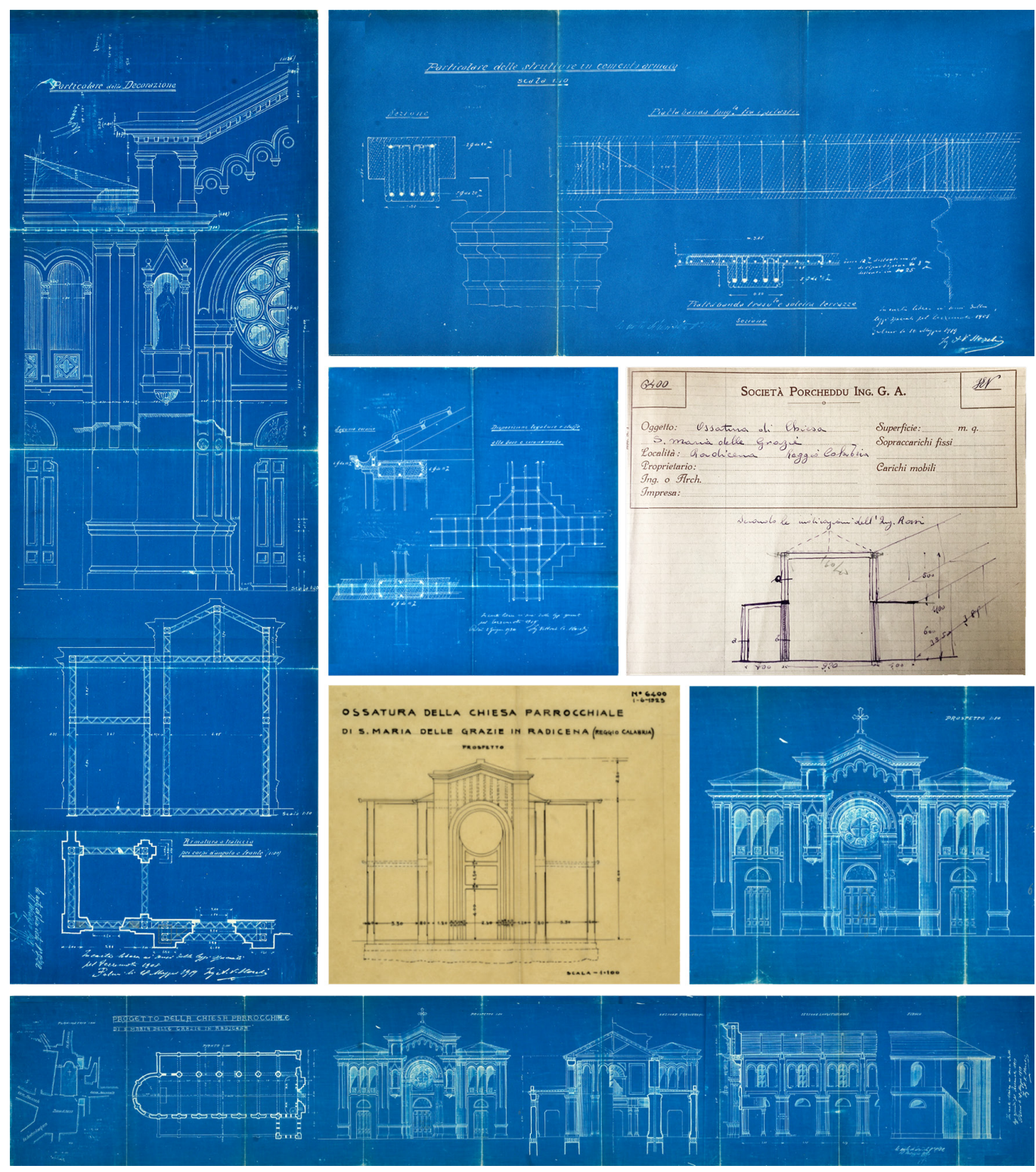
Avere la possibilità di riconoscere dietro le storiche architetture del Palazzo Provinciale (oggi Palazzo Corrado Alvaro), dei Tribunali, della Prefettura, del Palazzo delle Poste e Telegrafi, la presenza di un'ossatura strutturale rispettosa degli intenti architettonici dei progettisti è cosa preziosa. I progettisti Camillo Autore, Pietro Paolo Farinelli, Osvaldo Armanni, Gino Zani, per citarne alcuni, hanno disegnato architetture che sono ispirate da una simbiotica relazione con le istanze di livello urbanistico, mentre gli elementi espressivi che ne delineano
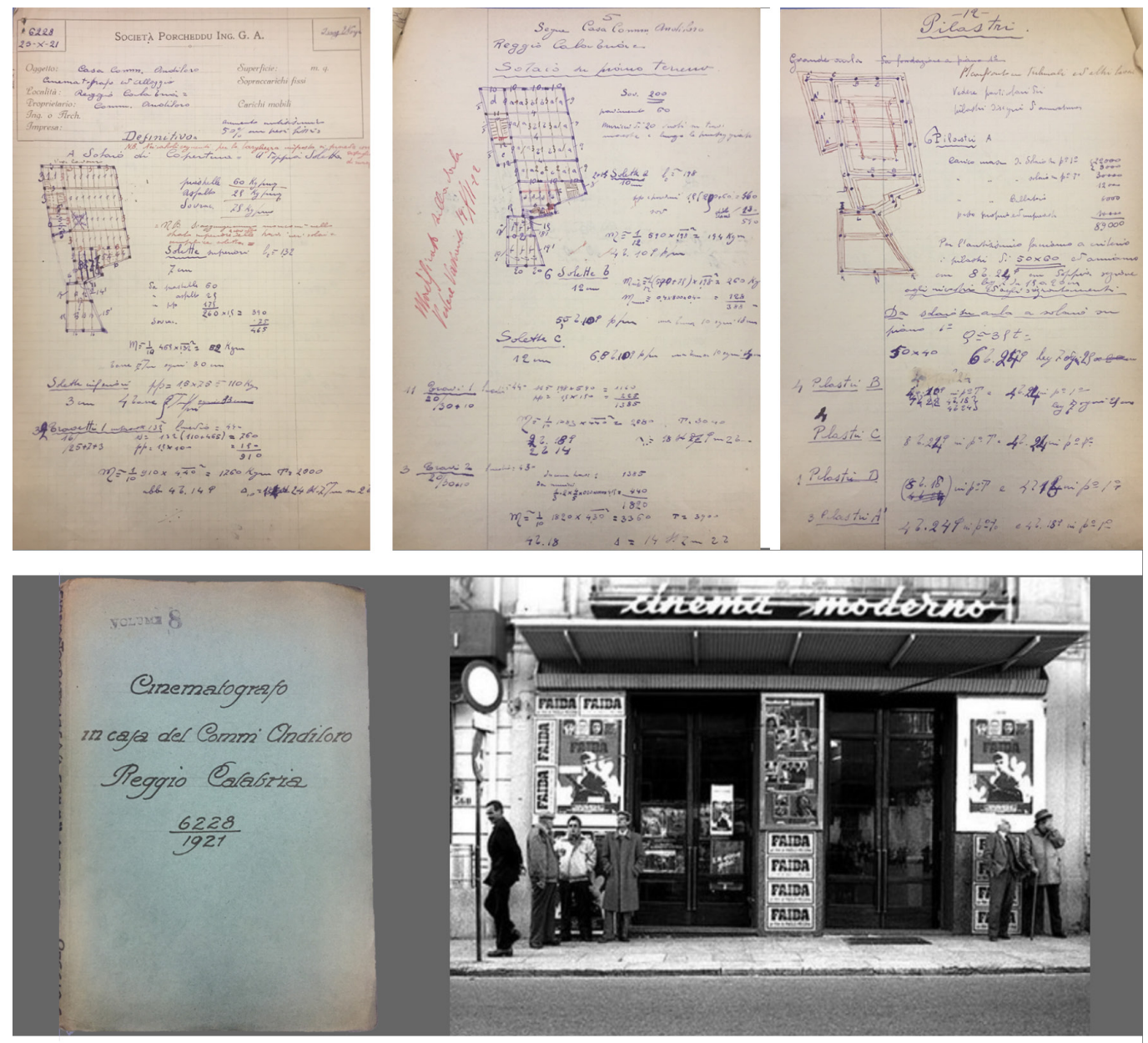

Fig. 6. Cinematografo in casa del Comm. Andiloro (6228/8). Pagine delle relazioni di calcolo, sopra, e disegni della sopra, e disegni della
distribuzione di pilastri e distribuzione di pilastri e
travi ai diversi piani, sotto. travi ai diversi piani, sot Al centro frontespizio
della pratica e foto dell'ingresso alla sala cinematografica Cinema Moderno, sul corso Garibaldi (1988 circahttps://filmscoop.org).

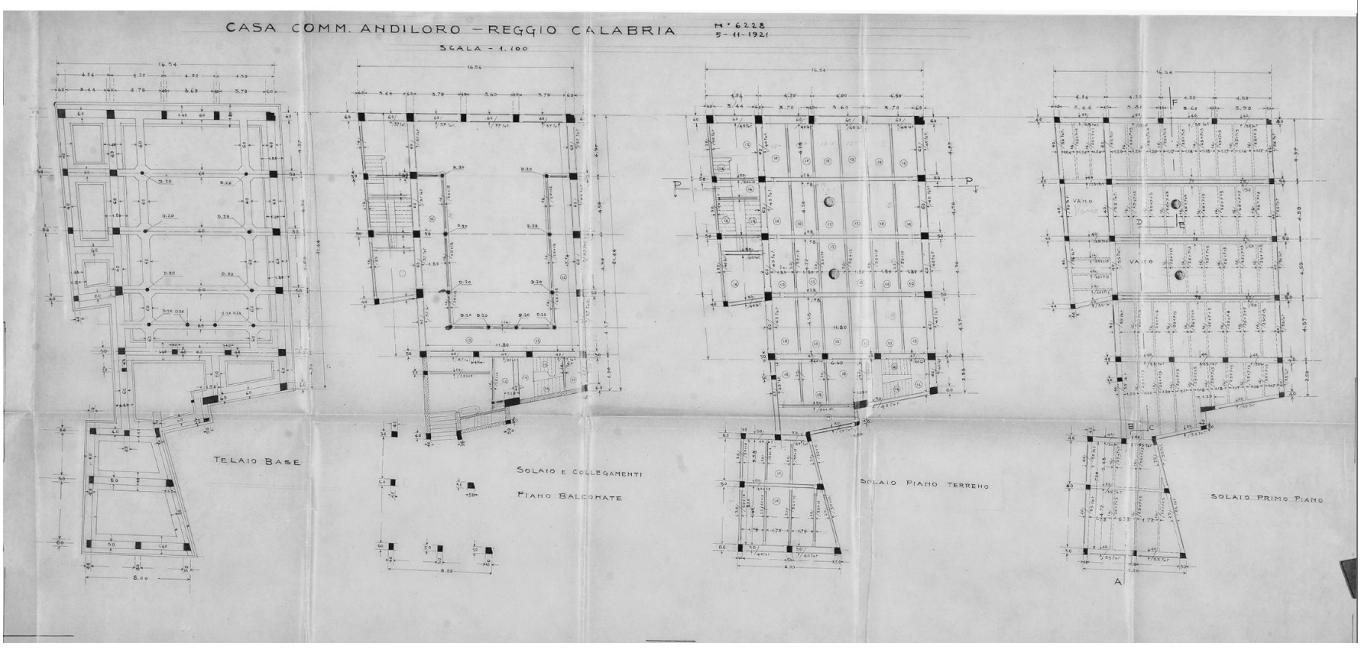


la loro individualità architettonica si richiamano vicendevolmente componendo un sistema armonizzato di quinte urbane per strade, slarghi e piazze del centro cittadino adatte a celebrare la nuova Reggio [5]. L'intento di sostenere il prestigio delle istituzioni ospitate, qualificandone il rango di rappresentanza, è perfettamente leggibile anche nei disegni dedicati all'impianto funzionale-distributivo che si esprime attraverso articolazioni planimetrico-spaziali tipologicamente definite. Si tratta di soluzioni che si mantengono entro una griglia di alternative connotate da allineamenti geometrici e ricorrenze modulari attente alle esigenze della progettazione strutturale, regolata da cogenti prescrizioni antisismiche, e interessate a razionalizzare il processo costruttivo per velocizzare fasi e tempi dell'imponente opera di ricostruzione. I particolari architettonici e gli elementi di finitura e decorazione, descritti nelle loro sagome di ingombro e rappresentati con perizia e precisione anche nei disegni dei complessivi, contribuiscono a informare i responsabili del calcolo strutturale ribadendo la stretta collaborazione richiesta tra concezione architettonica ideata e relative soluzioni tecnologiche. La selezione dei disegni operata per illustrare attraverso le immagini alcune delle considerazioni espresse è partita dall'esame di una delle ultime mappe catastali redatta prima del 1908: Centro urbano di Reggio Calabria che riporta la situazione dell'edificato al I 875 aggiornata al I878 e al 1899 . I disegni architettonici, comprensivi dell'impianto distributivo, (figura di copertina, figg. 2, 3) sono copie originali ricevute dall'impresa, basi geometrico-dimensionali necessarie per definire il sistema del telaio strutturale.
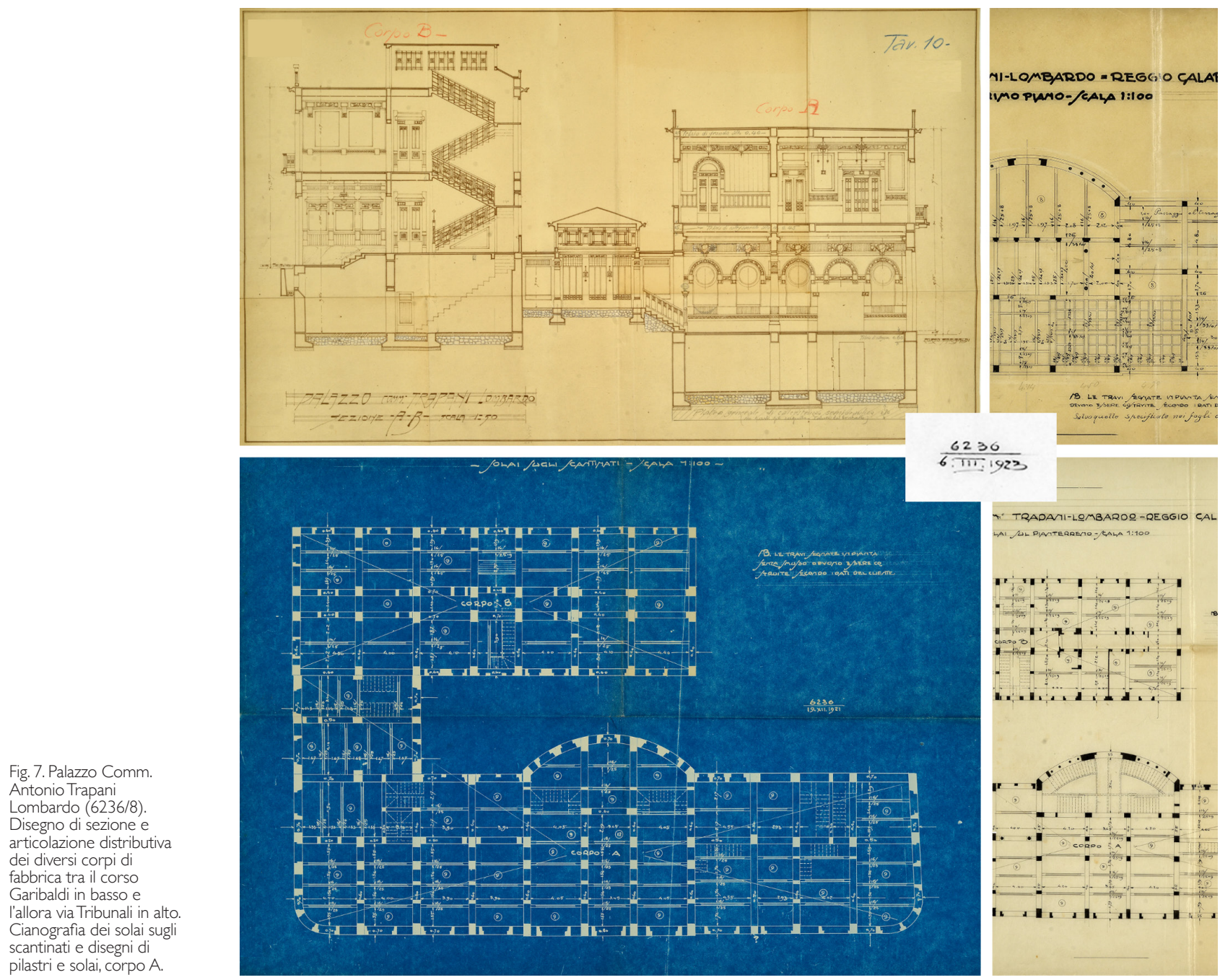


\section{Dentro la fisicità delle apparenze un ordito di armature resistenti}

Gli elaborati derivanti dal calcolo e approntati per l'esecuzione costruttiva corroborano questa visione di auspicata integrazione tra prassi compositiva e nuove sperimentazioni tecnologiche: nel corpo vivo dell'organismo edilizio ferri e staffe armano le membrature di calcestruzzo e, invisibili, sostengono dalle fondazioni alle coperture masse e volumi degli edifici per rispondere a carichi e sollecitazioni (fig. 4). Sono l'esito evidente del rinnovamento operato dalle applicazioni ingegneristiche nel campo della progettazione strutturale e frutto degli imperativi di sicurezza perseguiti dalle amministrazioni ministeriali e dagli uffici speciali locali, disposizioni ritenute idonee per ottemperare agli obblighi legislativi emanati per la ricostruzione post-sismica, per essere resilienti, si direbbe oggi, in vista di possibili nuovi eventi calamitosi. I disegni diventano tracce ricorrenti contenute all'interno di elaborazioni di differente grado di definizione: talvolta sono semplici schizzi appuntati per descrivere la trama della disposizione dei pilastri e dei solai adottata per l'impostazione dei calcoli, altre volte campiture policrome colorano le basi di matrice architettonica per definire gli schemi dei pilastri (o degli orizzontamenti) annotando le differenti tipologie geometriche e dimensionali, altre ancora sono elaborati molto dettagliati redatti per chiarire soluzioni complesse, o poco usuali, da trasmettere per la corretta esecuzione dei lavori (figg. 5, 9).

Nelle relazioni di calcolo le questioni si affinano conformando soluzioni sempre più dettagliate che si riflettono in formalizzazioni che le tavole grafiche registrano attraverso dettagli a scale diverse. Nei casi più complessi ai fini della messa in opera esecutiva alle notazioni simbologiche si sostituiscono redazioni iconografiche di maggior grado comunicativo, utili per le verifiche burocratiche e per le indicazioni operative rivolte alle maestranze (figg. 4,6).
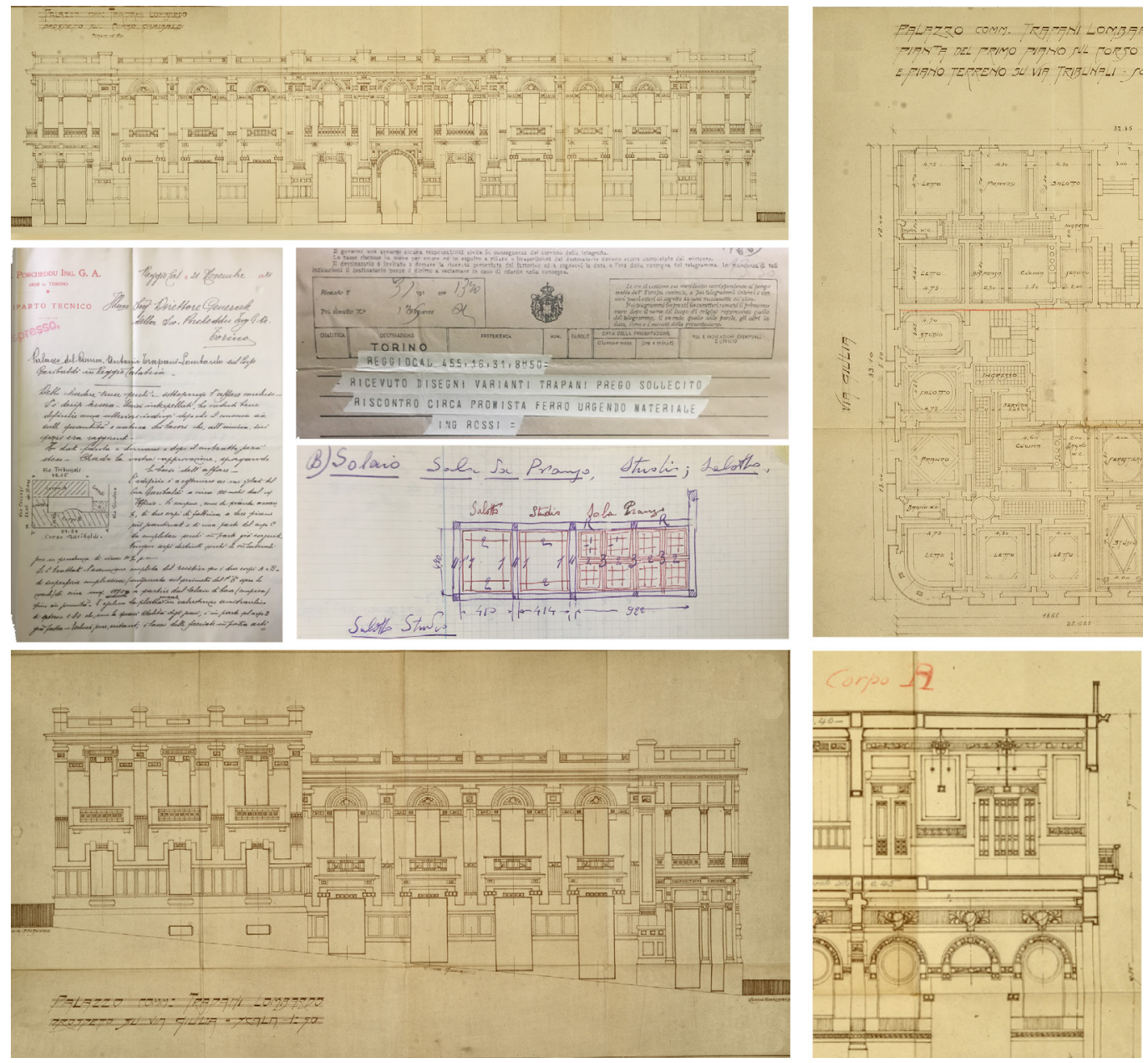
Per assolvere correttamente alla sua funzione conoscitiva, la rappresentazione deve scomporre il processo in una serie di sottosistemi semplificati diretti da obiettivi distinti, introdurre filtri specialistici, inventare sintassi linguistiche e nuovi lessici per garantire i nessi informativi necessari per una corretta ricomposizione del sistema nel suo complesso.

Un compendio di esemplificazioni è sembrato mezzo efficace per avvalorare le riflessioni espresse. Nella sintesi raccolta l'articolazione spaziale del sistema intelaiato di livello generale si confronta con i successivi livelli di dettaglio. Gli stralci sono tratti da alcune pratiche ritenute maggiormente significative, tra queste rimane traccia di alcuni lavori che registrano una committenza privata due casi che sono interessanti perché permettono di far notare come la prassi operativa dell'impresa appare consolidata (figg. 7, 8), e segue gli stessi rigorosi canoni di cura redazionale adottata per gli interventi di maggiore complessità [6].

\section{Nota conclusiva, quasi una confessione}

Ho provato a sintetizzare, ma ho tralasciato molto. I ricordi personali e familiari li ha tenuti nascosti il doveroso pudore che cela le cose intime, e tuttavia aleggiano nei luoghi attraversati e si intrecciano sottilmente con gli interessi scientifici che ho tentato di condensare in riflessioni da condividere o mettere in discussione. Durante l'itinerario ho percorso, non solo metaforicamente, strade frequentate per aprire scenari sul disegno, per connettere e ridurre le apparenti distanze tra le sue varie espressioni, spero di esserci riuscita.

Fig. 9. Palazzo dei Tribunali (5269/5). Due disegni molto diversi, la figura di copertina e quest'ultima illustrazione, divengono esempi emblematici che qualificano il ruolo della rappresentazione grafica che si conferma tramite fondamentale per documentare e prendere decisioni: mentre la prima immagine riproduce concezione architettonica di livello esecutivo trasmessi da Reggio a come base geometrica per l'impostazione statico-strutturale statico-strutturale
(sezione trasversale su vestibolo principale e aule per le udienze penali), il disegno qui sopra evidenzia come la definizione del telaio antisismico fu perfezionata in momenti successivi sfruttando l'indispensabile collaborazione tra
il referente locale dell'impresa Ingerner dessi impresa Ingegner Rossi e i progettisti. Sulla pianta del telaio di base e pilastri sono annotati schizzi, correzioni, sezion di componenti ribaltate campiture policrome che registrano configurazioni definite e varianti utili per la redazione dei disegni costruttivi.

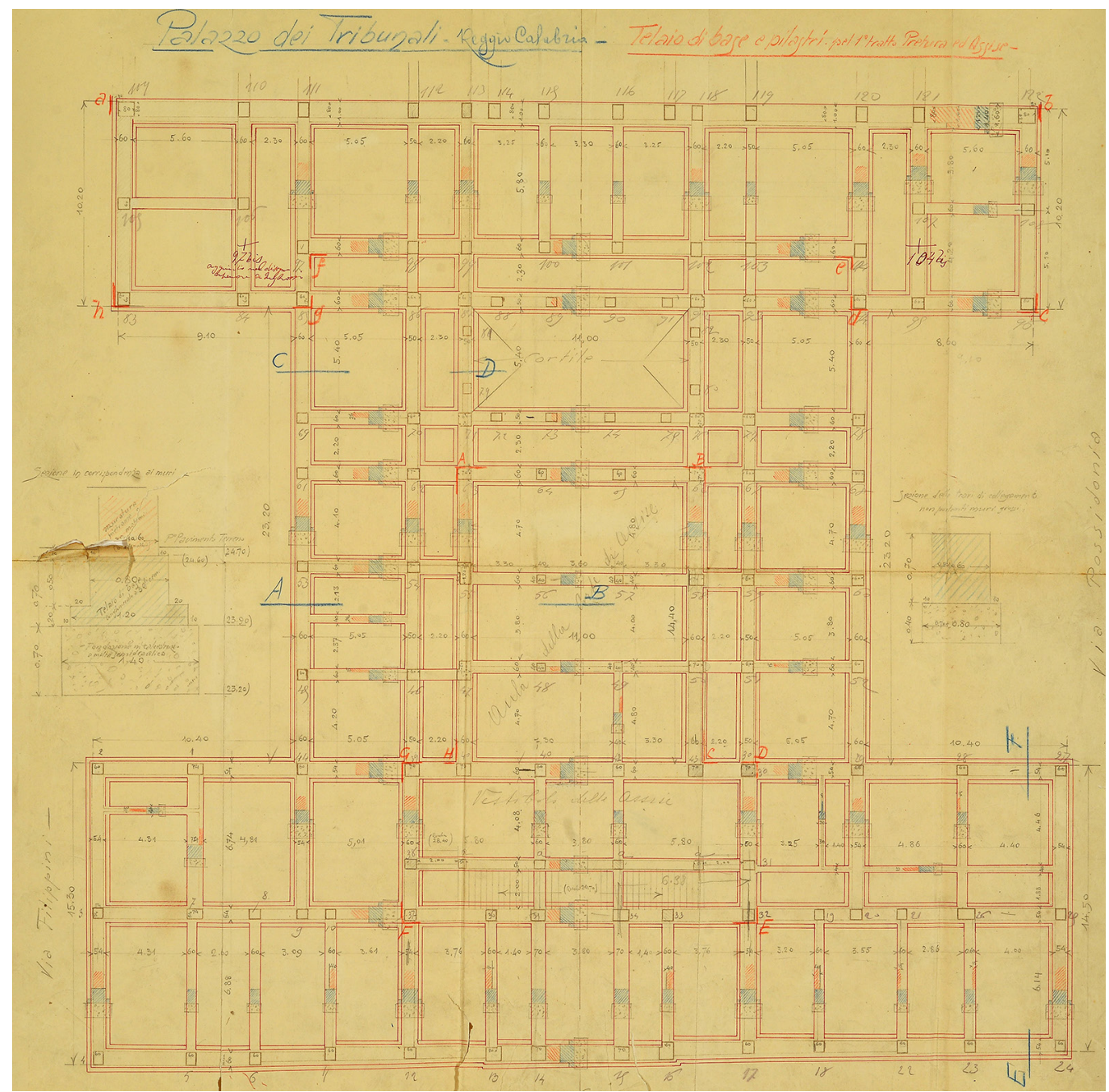




\section{Note}

[I] Per illustrare l'importanza della Società Porcheddu, il suo significativo apporto assunto nella diffusione della tecnologia delle strutture in conglomerato cementizio armato, del sistema-brevetto Hennebique e del contesto culturale e tecnico entro il quale l'impresa operò si segnalano i volumi di: Nelva Riccardo, Signorelli Bruno 1990; lori Tullia, A. Marzo Magno 201 I.

[2] Nelva, Signorelli 1990: "L'archivio è ordinato in faldoni per località e per anni. Le pratiche sono datate dal I 895 al 1933 (con esclusione di alcuni lavori non utilizzanti il c.c.a., antecedenti il 1895). Suddiviso nelle seguenti località o zone: Torino (I02); Piemonte (70); Milano-Lombardia (26); Roma ( 19); Veneto (I I); Liguria (58); Genova (62): Messina Palermo (I I); Reggio Calabria (8); Sardegna (3); Tripoli (2);Zone diverse ( I 3).' Tra parentesi il numero di dossier. Oggi lo storico patrimonio è custodito presso il Dipartimento di Ingegneria Strutturale, Edile e Geotecnica del Politecnico di Torino.

[3] Insieme con la legge n. 8 e n. 12 del 12/01/1909, riguardante Provedimenti e disposizioni in seguito al terremoto del 28/I2/1908, e al Regio D. I8/04/1909, n. 193, in data I3/07/1910 n. 466 e 28/07/I9 | I n. 482 entravano in vigore le disposizioni per la costruzione degli edifici pubblici governativi.

[4] Ingegnere, incaricato dal sindaco Valentino di redigere il nuovo Piano Regolatore della città di Reggio Calabria approvato nel 191।, nel 1914 ricoprì la carica di assessore comunale ai lavori pubblici; benché il suo Piano avesse come riferimento il Piano Mori del 1785, redatto dopo il terremoto del |783, e i piani di ampliamento del I 868 e del I898, l'introduzione di una serie di piazze, slarghi e aree verdi all'interno della scacchiera degli isolati è ideazione urbanistica di una rinnovata visione che ha connotato per molto tempo il paesaggio urbano reggino.

[5] Segnalo il bel libro di Daniele Colistra, con presentazione a firma di Massimo Giovannini, edito nel 1999 sulla morfologia urbana e sull'architettura di Reggio, citato in bibliografia, cui si rimanda per gli approfondimenti sulla cultura del progetto di quegli anni.

[6] Palazzo del Comm. Trapani Lombardo e Cinematografo in casa del Comm. Andiloro interventi avviati nel 1921, entrambi sul Corso Garibaldi.

\section{Riferimenti bibliografici}

Colistra Daniele (1999). Reggio Calabria L’Architettura e la Città. Reggio Calabria: Jason Editrice.

Gabetti Roberto (1955). Origini del calcestruzzo armato, parte I e II.Torino: Edizioni Rata.

Iori Tullia (200 I). II cemento armato in Italia dalle origini alla seconda guerra mondiale. Roma: Edilstampa.

Iori Tullia, Marzo Magno Alessandro (20 I I). I 50 anni di storia del cemento in Italia. Le opere, gli uomini, le imprese. Roma: Gangemi Editore.

Nelva Riccardo, Signorelli Bruno (1990). Avvento ed evoluzione del calcestruzzo in Italia: il sistema Hennebique. Milano: Edizioni di scienza e tecnica.

Novello Giuseppa, Bocconcino Maurizio,Vincenzo Donato (2017). Sperimentalismo grafico e invarianze di metodi nel disegno del cemento armato agli inizi del 1900: l'innovazione esige adattamento e invenzione di codici. In di Luggo Antonella et al. (a cura di). Territori e frontiere della rappresentazione. Atti del $39^{\circ}$ Convegno Internazionale dei Docenti delle Discipline della Rappresentazione. Napoli, I4- 16 settembre 2017, pp. 859-862. Roma: Gangemi.

Novello Giuseppa, Bocconcino Maurizio Marco (20 I 8). Archivi vivendi: nuove alleanze tra beni conservati, forme di rappresentazione e metodi di diffusione del patrimonio tecnico. In Minutoli Fabio (a cura di). L'intreccio dei saperi per rispettare il passato, interpretare il presente, salvaguardare il futuro, Atti VI Convegno Internazionale REUSO 2018 Documentazione, conservazione e recupero del patrimonio architettonico e sulla tutela paesaggistica. Messina, I I- I 3 ottobre 20 I 8, pp. 2603-26 I 4. Roma: Gangemi Editore.

Andavamo al cinema: <https://filmscoop.org/category/vecchie-sale-cinematografiche-italiane>.

Autore

Giuseppa Novello, Politecnico di Torino, pina.novello@polito.it

Per citare questo capitolo: Novello Giuseppa (2020). Memorie tecniche e ricordi familiari. Torino e Reggio Calabria nelle carte e nei disegni dell'archivio Porcheddu/Technical memories and familiar remembering. Torino and Reggio Calabria in the papers and in the drawings of the Porcheddu Archive. In Arena A., Arena M., Brandolino R.G., Colistra D., Ginex G., Mediati D., Nucifora S., Raffa P. (a cura di). Connettere. Un disegno per annodare e tessere. Atti del $42^{\circ}$ Convegno Internazionale dei Docenti delle Discipline della Rappresentazione/Connecting. Drawing for weaving relationships. Proceedings of the 42th International Conference of Representation Disciplines Teachers. Milano: FrancoAngeli, pp. 680-703. 


\title{
Technical Memories and Familiar Remembering. Torino and Reggio Calabria in the Papers and in the Drawings of the Porcheddu Archive
}

\author{
Giuseppa Novello
}

Abstract

Synthetic critical comments, images composed of drawings and other elaborations accompany the results of the research conducted on the documentary heritage contained in the Turin archives of the Società G. A. Porcheddu, with regard to the interventions of the company carried out in Reggio Calabria and its province, between 191 I and 1923.The analysis of the original architectural intentions and the answers offered by the solutions outlined for the static-structural system were a privileged field of investigation to reflect on the system of work that made it possible to overcome the pressing challenge of post-seismic reconstruction. Challenge that the archive materials, investigated through comparative methods interested in the instances deriving from the two processing environments, show that it was faced by adopting highly collaborative working methods. The considerations run through an itinerary that involves realizations of different importance and conception, accepting the cognitive tension intrinsically connected with some expressive forms of drawing, activated also to manage, with planning coherence, the operative complexity required by the criticality of the moment. It is pleasing to think that the documents not only represent a means of recomposing the system of the many relationships between clients, professionals and workers, but have also founded a winning alliance between Torino and Reggio, a partnership which, despite the geographical distance between the two cities, emerges from the past and is constantly renewed.

\section{Keywords}

Porcheddu archive, Reggio Calabria, structural and architectural concepts, drawing for design, antiseismic constructions.

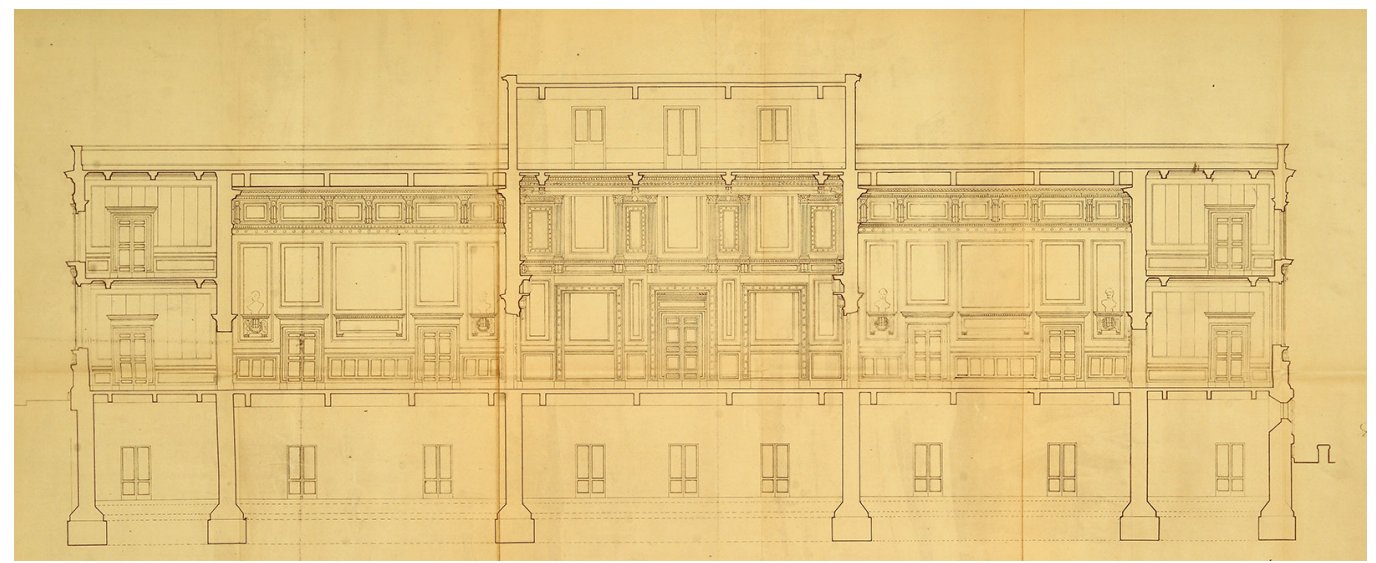


Some historical events of Italian engineering in the early decades of 1900 create a direct connection between Turin and Reggio Calabria, between the technical memories there are glimmers of familiar memories, this contribution would evoke vague correspondences.

Adhering to the explicit invitation to go beyond the "simple rational thought" expressed in the words of introduction chosen by the organizers of this 42nd UID Conference, I thought to propose some reflections on the relationship that has been established between architectural intentions and technological-constructive responses resulting from severe and unavoidable environmental demands such as those given by the geological and geodynamic context of the area that includes Reggio and Messina; in reality, among the words and images of this contribution, a red thread collects a series of more or less obvious plots that I hope can be followed to discuss them. An analogy of relationships inspired by the complex interpretative interweaving that recalls on the one hand the myth of Prometheus, the titan chained by Zeus for having given fire to humanity, and on the other that of Mnemosyne, repository of memory and mother of the Muses; an encounter invoked to provide multiple reading filters, glances to bind intentions and outcomes of the research action carried out, following the hope that through this my representation, necessarily synthetic, "You can trace endless stories that are hidden in words, that generate figures, that have unfathomable semantic depths".

\section{Context references and sources}

It all began when I decided to explore some of the previous ideas of investigation oriented to explore some expressive forms of drawing, related to the executive and constructive field, qualified by a cognitive tension that connects architecture and structure with inseparable links. As elsewhere noted [Novello et al. 20 I7], speaking of the graphic experiments adopted in the representation of reinforced concrete, in the first decades of its introduction, I would like to reiterate that: "with regard to the entire process of elaboration, from the conceptual to the constructive moment, the investigations on design and representation are particularly stimulating if one takes care to concentrate research on the first empirical adaptations promoted within the relative design and production practices". The results of those investigations had led to underline that: "For new conceptions new designs are needed, because there is no doubt that at the moment in which design is produced for innovation, it must go along paths that had not been beaten until then, substituting or flanking traditional forms, consolidated by a use that has become shared and known practice, with other expressive inventions" [I].

I wanted to continue those first explorations, conducted then in the company of young friends, narrowing the scope of the investigation to dedicate it to a place that is in my heart. To find myself in Reggio I travelled with greater care through the territories and scenarios of an archive that speaks of Reggio's architecture and that has given me new emotions.

Among the papers and drawings kept in the Archivio della Società Giovanni Antonio Porcheddu, there are some documents concerning a series of projects and works carried out by the Turin company in Calabria and Sicily, mostly attributable to that period of lively planning and construction ferment following the interventions started after the earthquake that in 1908 hit Reggio and Messina so ruinously. Among the twelve territorial divisions that mark the original classification [2] adopted by the Company to preserve the documentation of its work from 1895 to 1933, eleven folders refer to the activities of the company carried out between Messina and Palermo and eight to the works concerning eighteen works located in the city of Reggio and five in its provincial territory. The approximately two thousand six hundred files that gather all the works on which the Company worked are numbered 
in ascending order within distinct folders, collected in three hundred and eighty-five folders; divided by location and year, they offer a very varied repertoire of documentary data, so much so that by examining their recurrent articulation it is possible to draw a fairly detailed picture of the organization of the enterprise and its operating methods. Papers and drawings weave a composite weave, variegated in consistency according to the importance of the works referable to the individual files, but an orderly archiving system (never random, so much so as to provide a specially printed forms for the various sectors of activity, already in the drafting phase), takes charge of collecting the materials by bringing them together in types of documentation, following a method that adopts criteria of subdivision useful for the
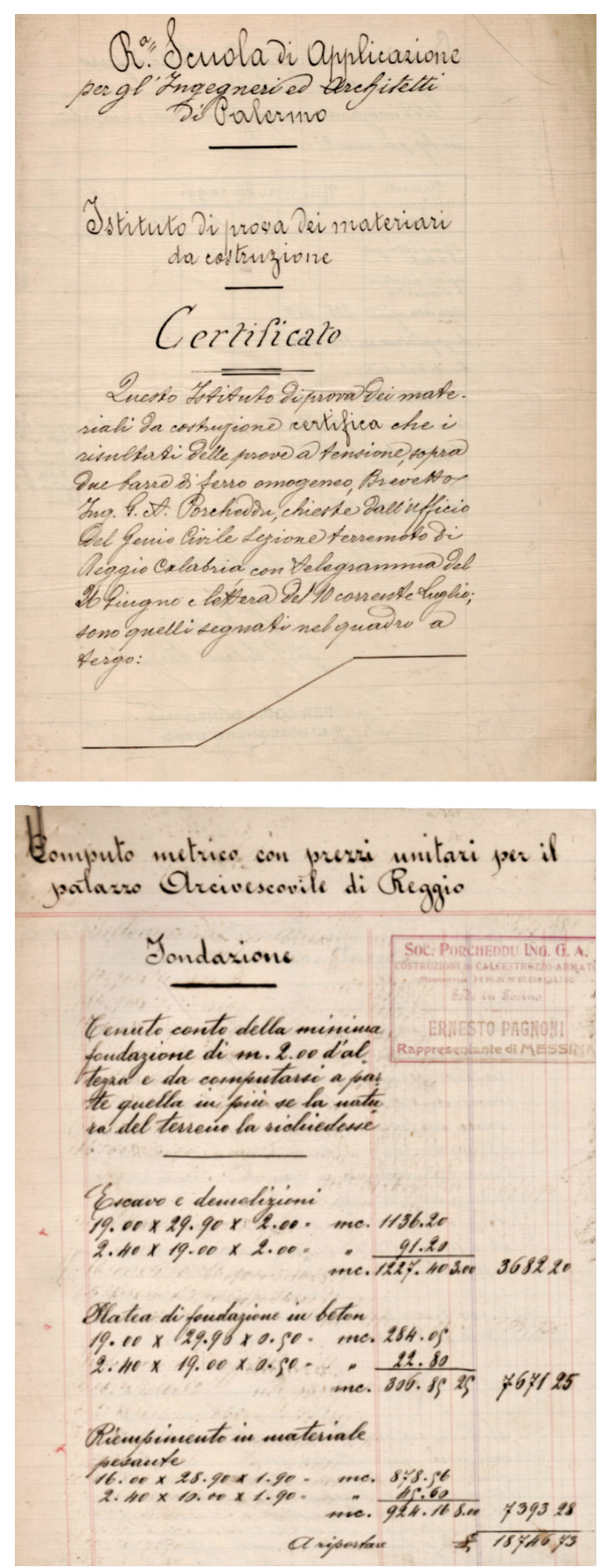
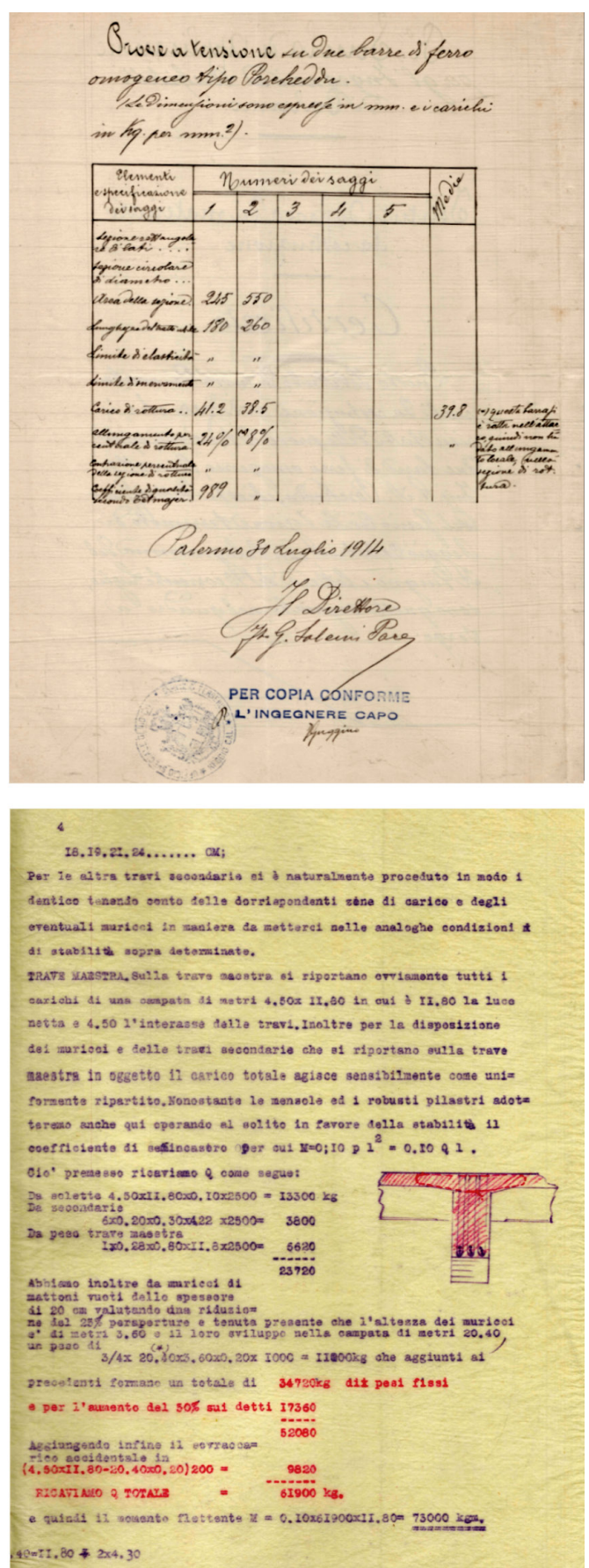

Fig. I. Test certificate on two iron bars "Porcheddu", Laboratory University of Palermo (above). Estimative metric calculation (palazzo Arcivescovile) and calculation report page (below). 

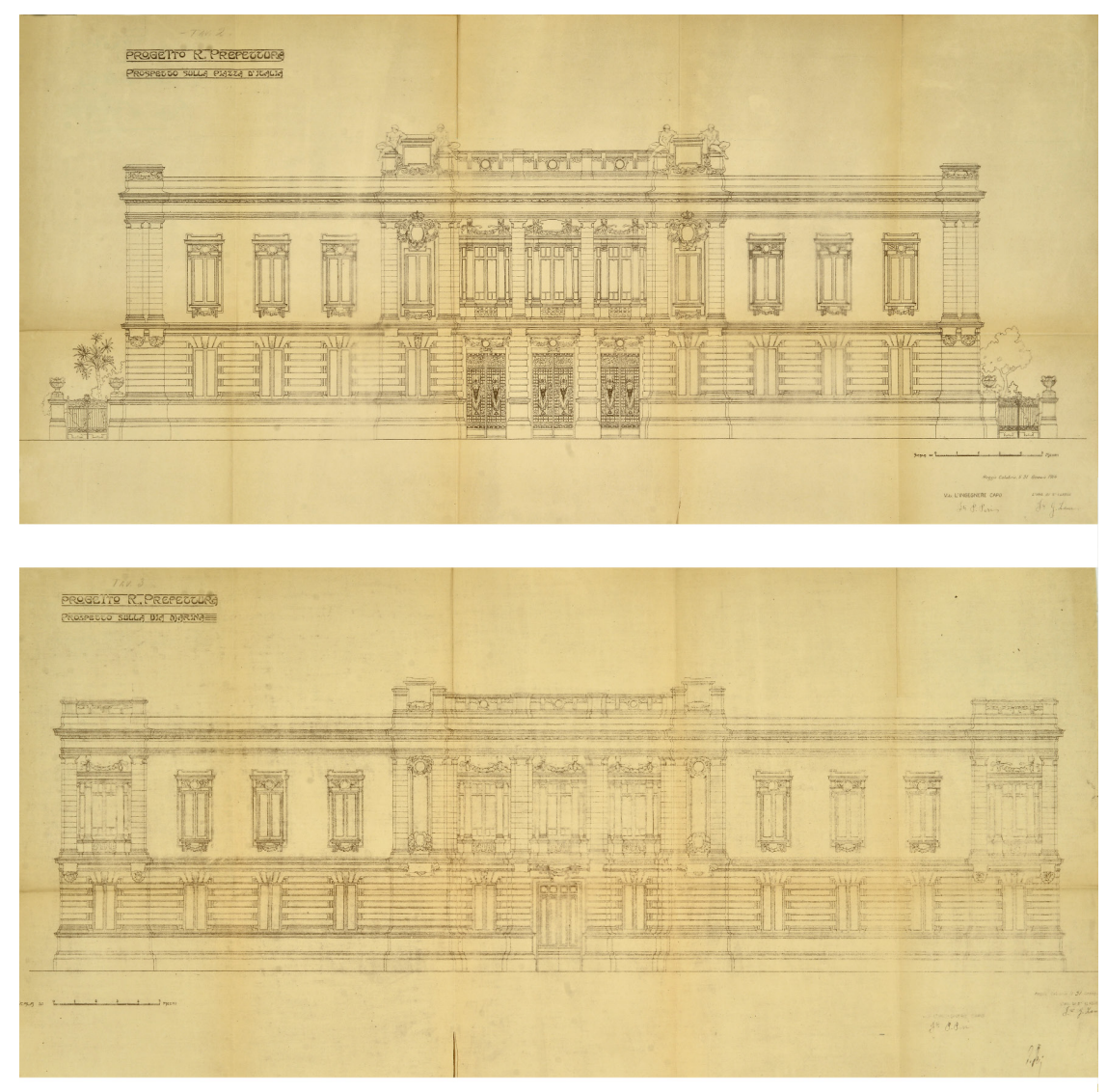

Fig. 2. Regia Prefettura (5270/4). The signatures of the Chief Engineer of Civil Engineering Peri and the second class engineer Zani sign the drawings sent to Porcheddu for

the definition of the

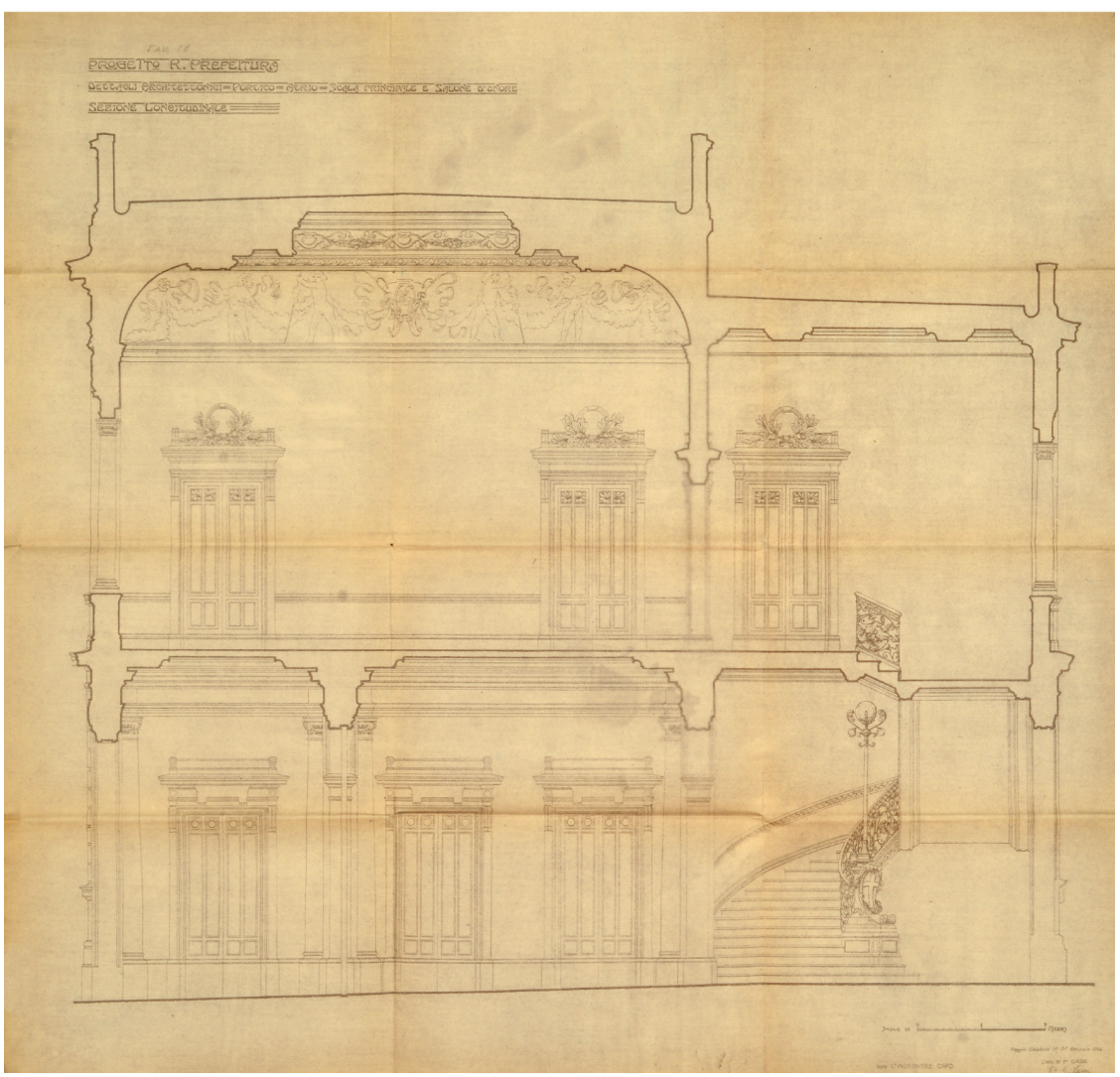


management of the complex of activities carried out. This is a systematic operation necessary to keep times and working methods under control, and to be able to verify commitments and resources, pursuing a constant monitoring that lasts for the entire duration of the executive process even when unavoidable unforeseen events interrupted its natural course, as happened in part during the years of the First World War.This systematic approach, originally pursued also in order to be able to operate in different places at the same time and to cope with different types of intervention, becomes a prerogative that makes it possible today to re-elaborate the information contained in that it has been preserved, making it possible to formulate hypotheses and offering many new interpretations.
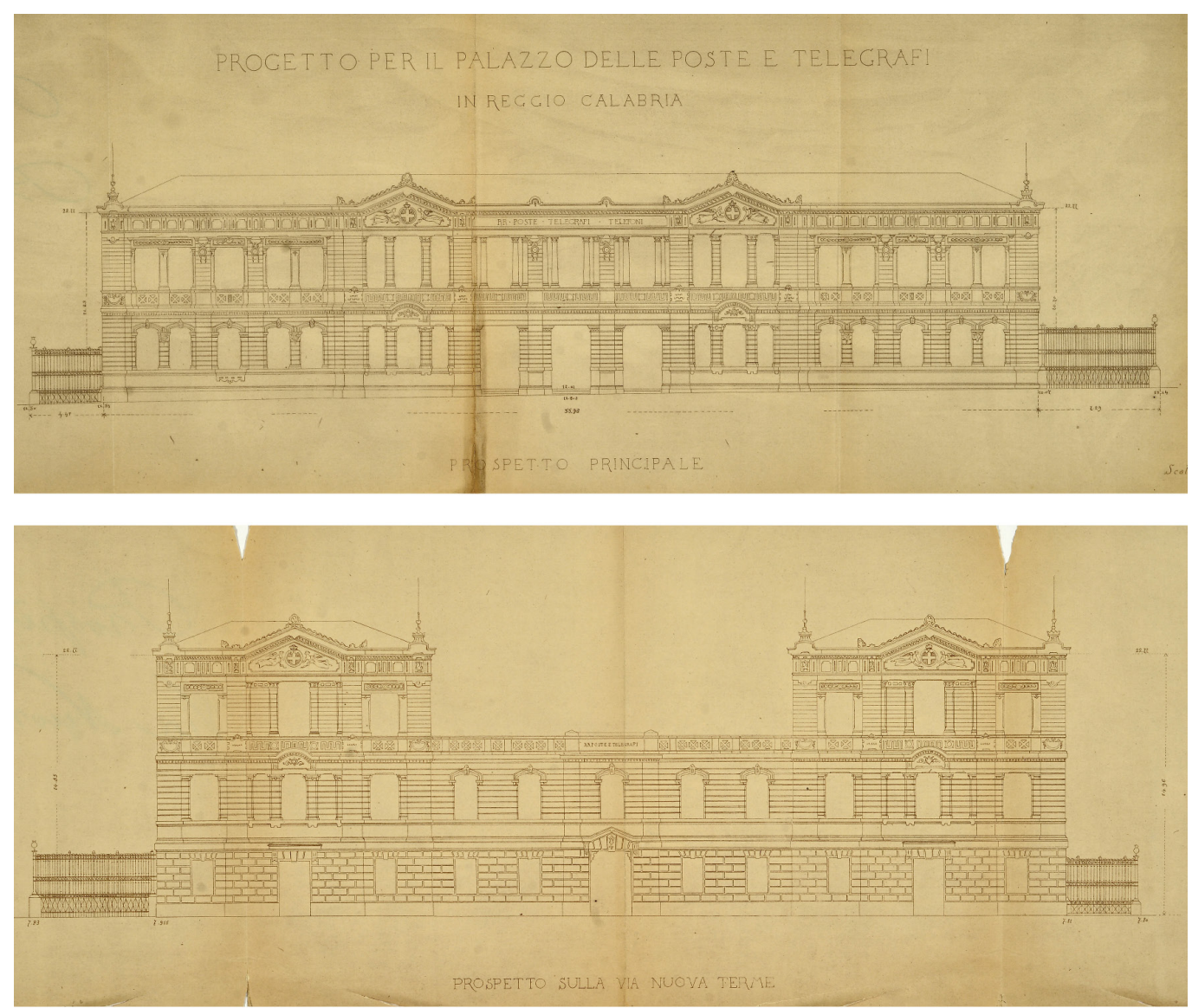

via Prefettura.

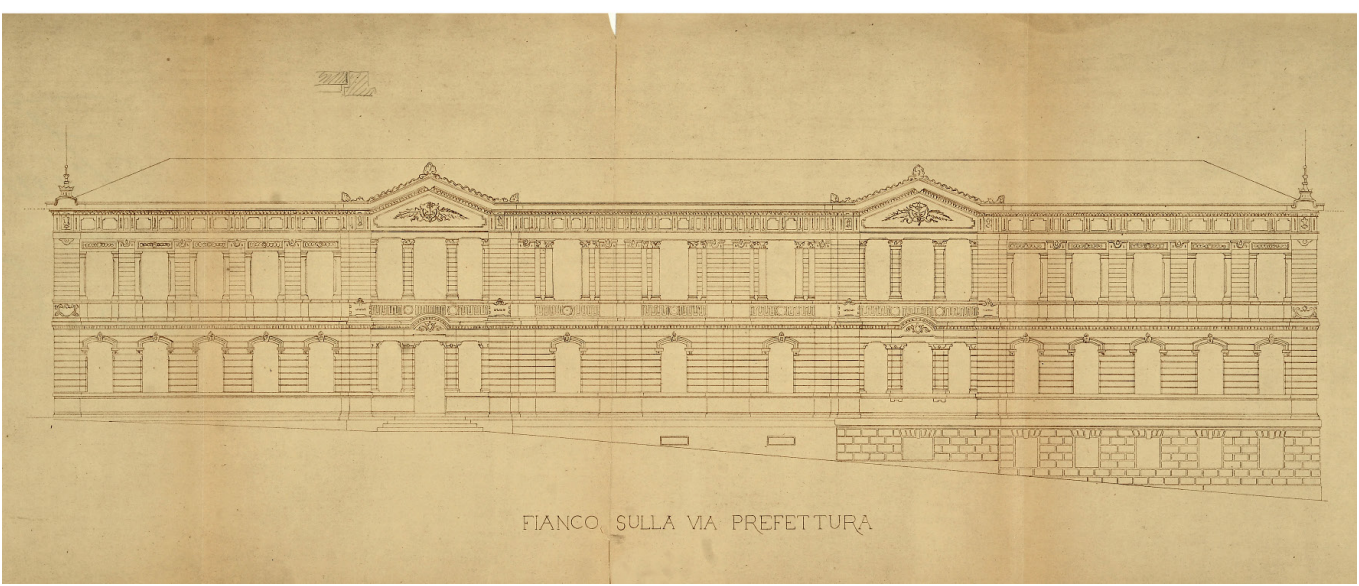


It is a matter of linking together documents that, in a direct or indirect way, renew their informative potential and are able to give back memory and testimony of a dense series of links that allow, today, to know or intuit many things: the relationships held with the various public and private clients, the internal workflow and that which existed between the Turin head office and the professionals who were its local representatives (engineers Pagnoni, Traverso and Rossi), the preliminary and definitive technical elaborations, the structural and economic calculation alternatives that were discarded and those chosen, the contract or supply contracts and the relative critical points, the memoirs relating to some unfailingly protracted controversies, the relationships held with the designers who created the architectural and distribution ideas for large and small interventions (fig. I). A set of traces that make the method and operational efficiency evident in an era (1911-1923, if one thinks of the interventions carried out between Reggio and the province) in which the communication systems between North and South were undoubtedly difficult both for people and for the supply and transport of the materials needed for the construction work.
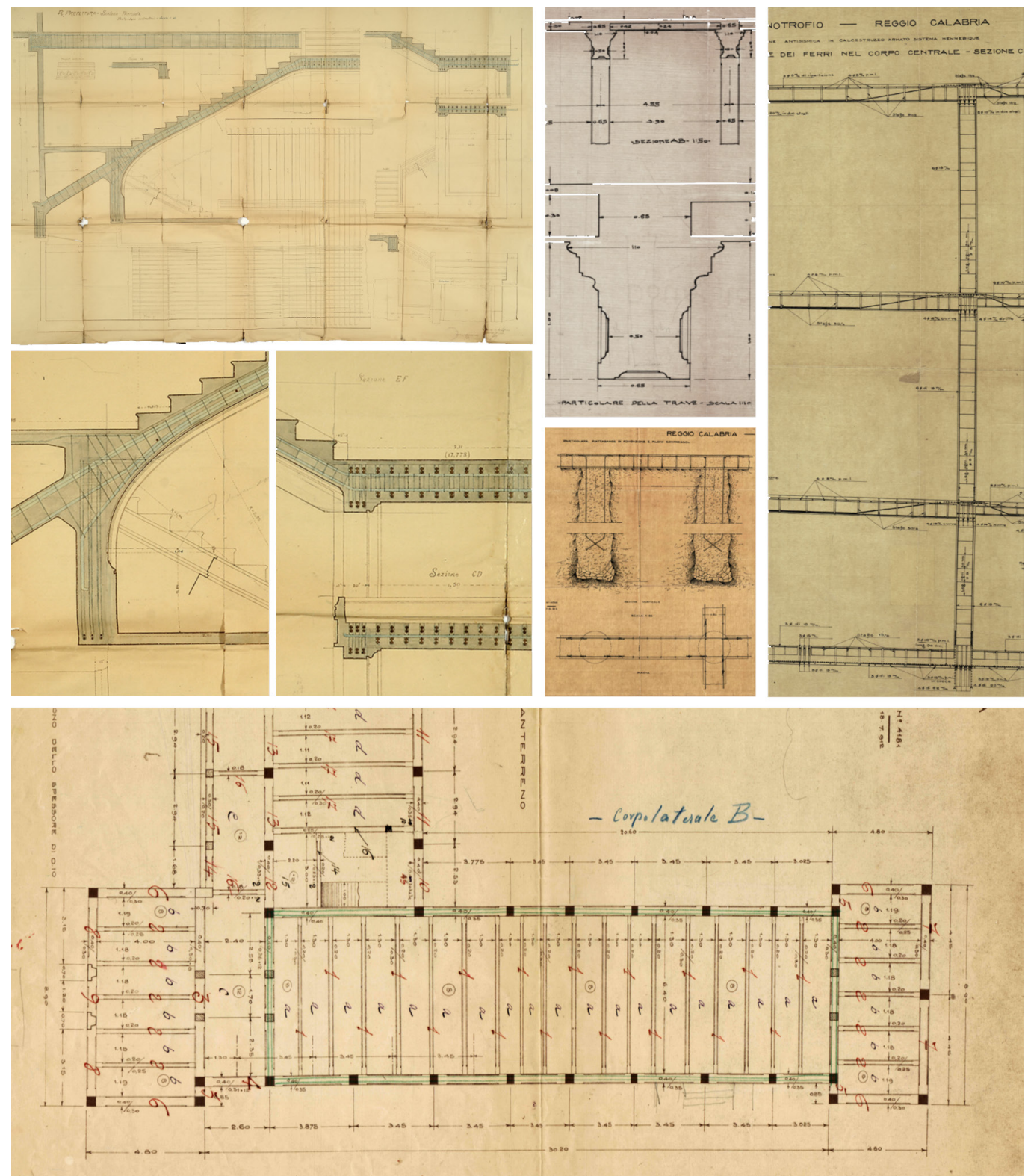
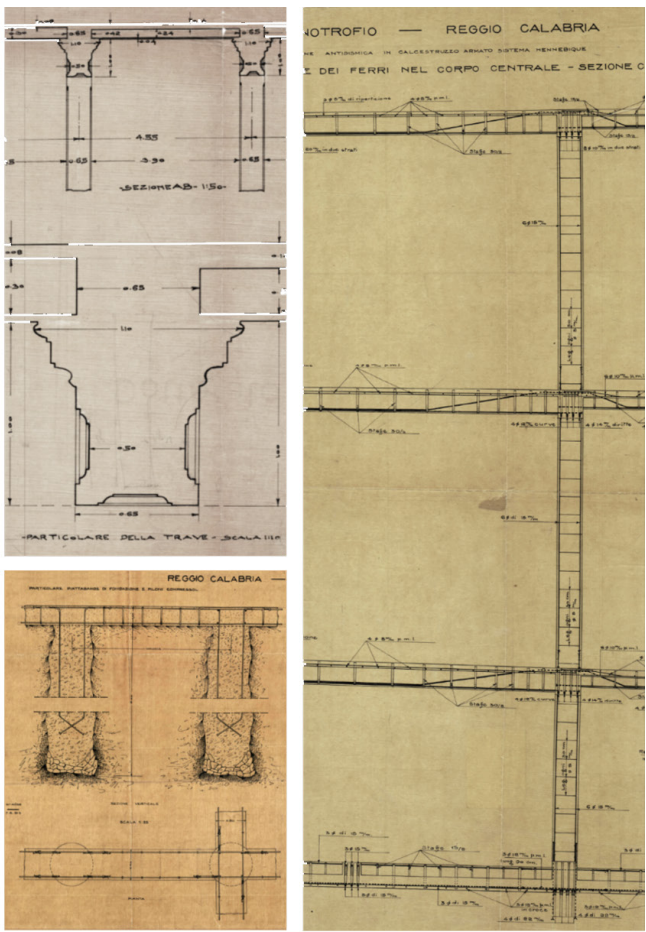

$i_{1}^{2}$
Fig. 4. Inside the volume shapes the structural articulation weaves invisible resistant wefts. Prefecture Staircase (5270/4), Beam shape and pile foundations Palazzo Poste e Telegrafi (4658/7), types of beam and floors 


\section{Reasons to continue browsing through drawings and papers}

The long experience of consulting the archive has facilitated me in this second phase of exploration, which I conducted with renewed pleasure because the rich heritage of drawings inherent to the works produced for Reggio Calabria is qualified by some peculiar attributes of great interest, precisely in relation to the close alliance between the static-structural tension [3] invoked and verified by the anti-seismic directives conceived for reconstruction by engineers and the architectural compositional solutions designed by architects. A design that has affected many buildings of the city's institutions and services, cornerstones of an urban identity deeply marked by the trauma of the earthquake of 1908, whose recomposition is the result of Pietro De Nava's master plan [4], which has strongly changed the environmental image of the capital through a series of sensibly coordinated building interventions, emerging in a wider landscape that, through panoramic shrewdness, projects and includes the expanse of the sea and the Sicilian coast. The same image recalled by my first memories, that of an elegant, composed and luminous urban scenography, a perception that has always been impressed in my memory.
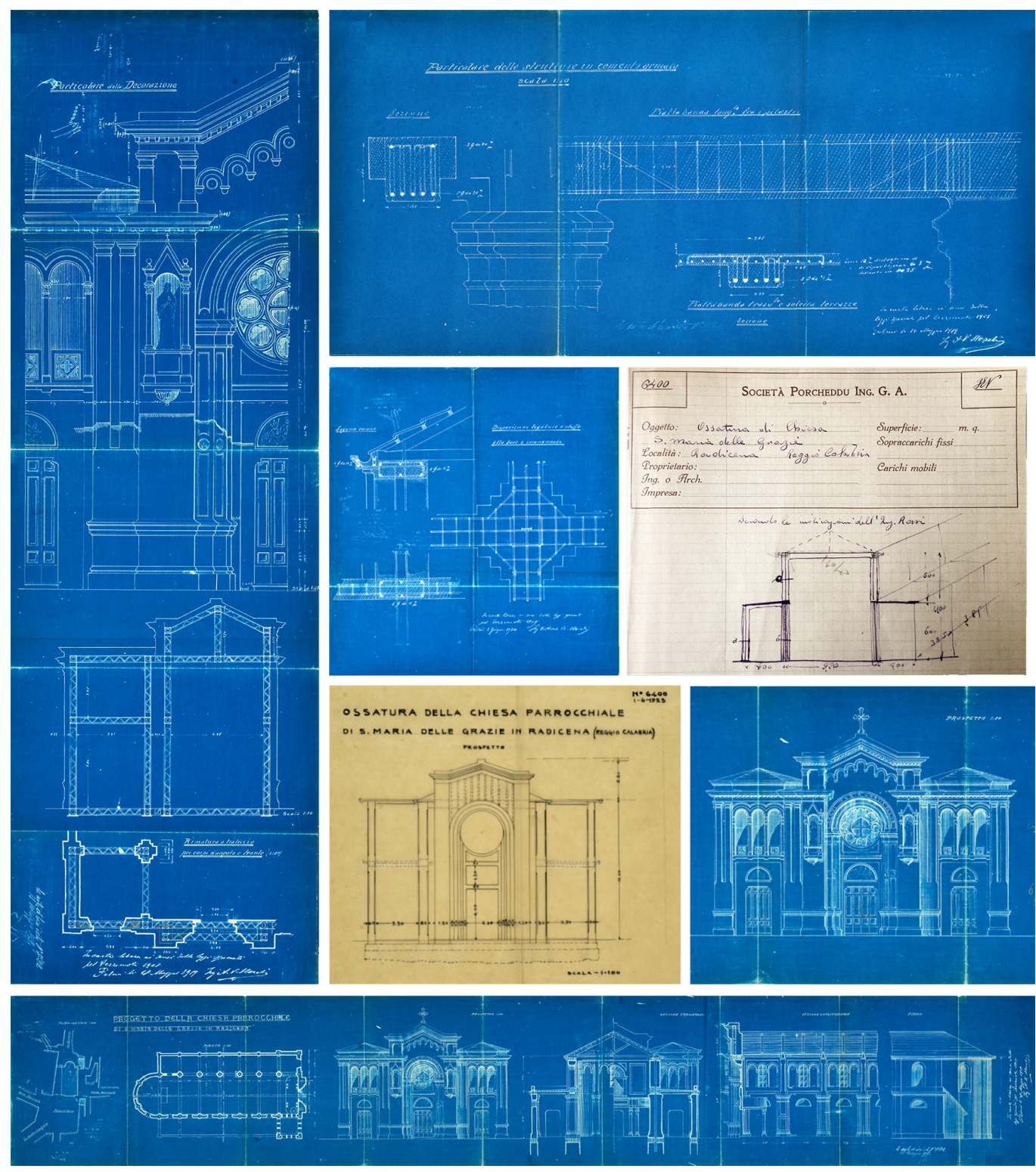
Having the possibility to recognize behind the historical architecture of the Palazzo Provinciale (today Palazzo Corrado Alvaro), the Courts, the Prefecture, the Post Office and Telegraphs, the presence of a structural framework that respects the architectural intentions of the designers is a precious thing. The designers Camillo Autore, Pietro Paolo Farinelli, Osvaldo Armanni, Gino Zani, to name but a few, have designed architectures that are inspired by a symbiotic relationship with the demands of urban planning, while the expressive elements
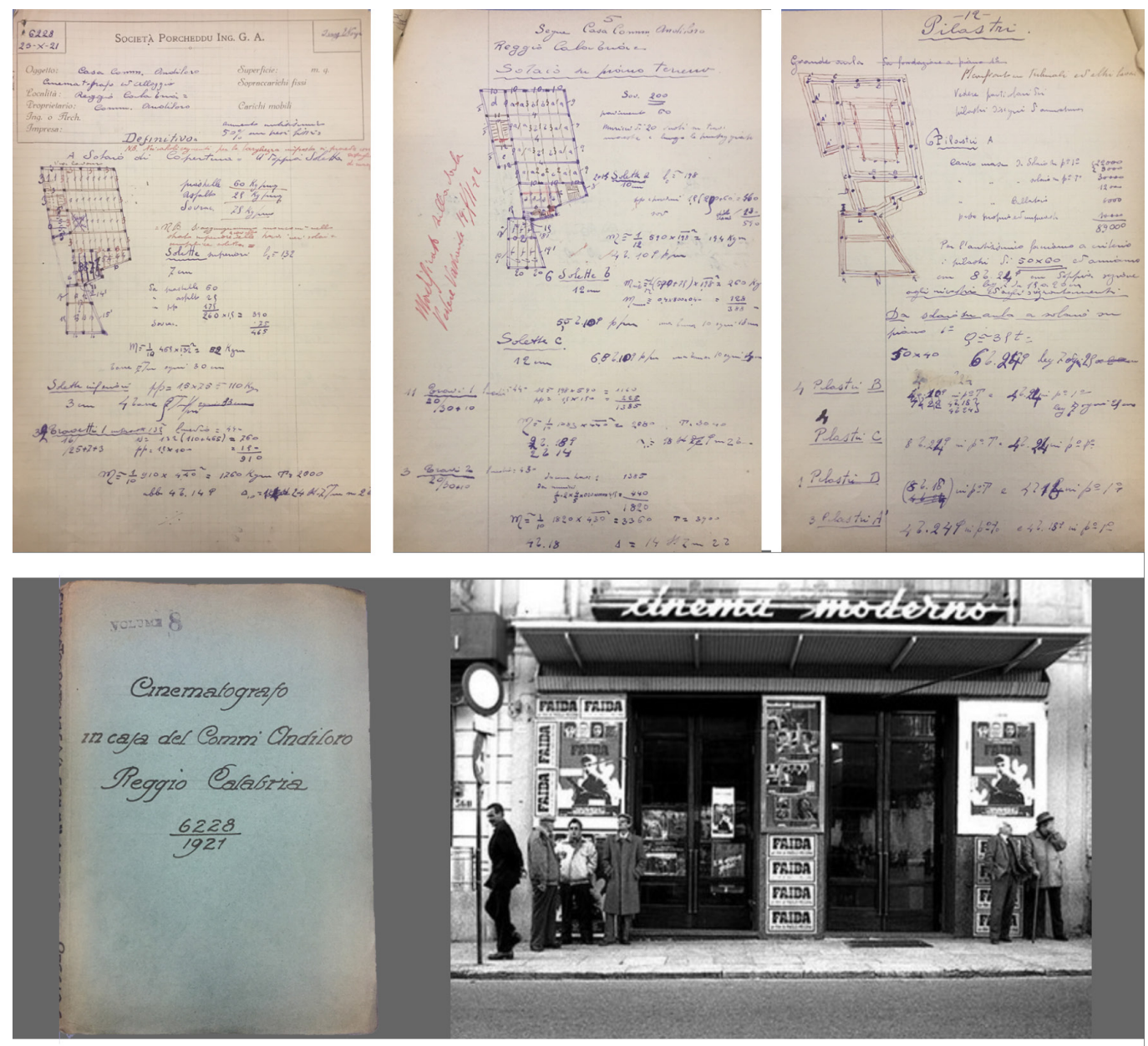

Fig. 6. Cinematograph in Comm. Andiloro's house (6228/8). Pages of the calculation reports, above. and drawings of the distribution of pillars and beams on the different floors, below. In the center the title page of the file and photos of the entrance to the Cinema Moderno, on Corso Garibaldi (1988-https:// filmscoop.org).

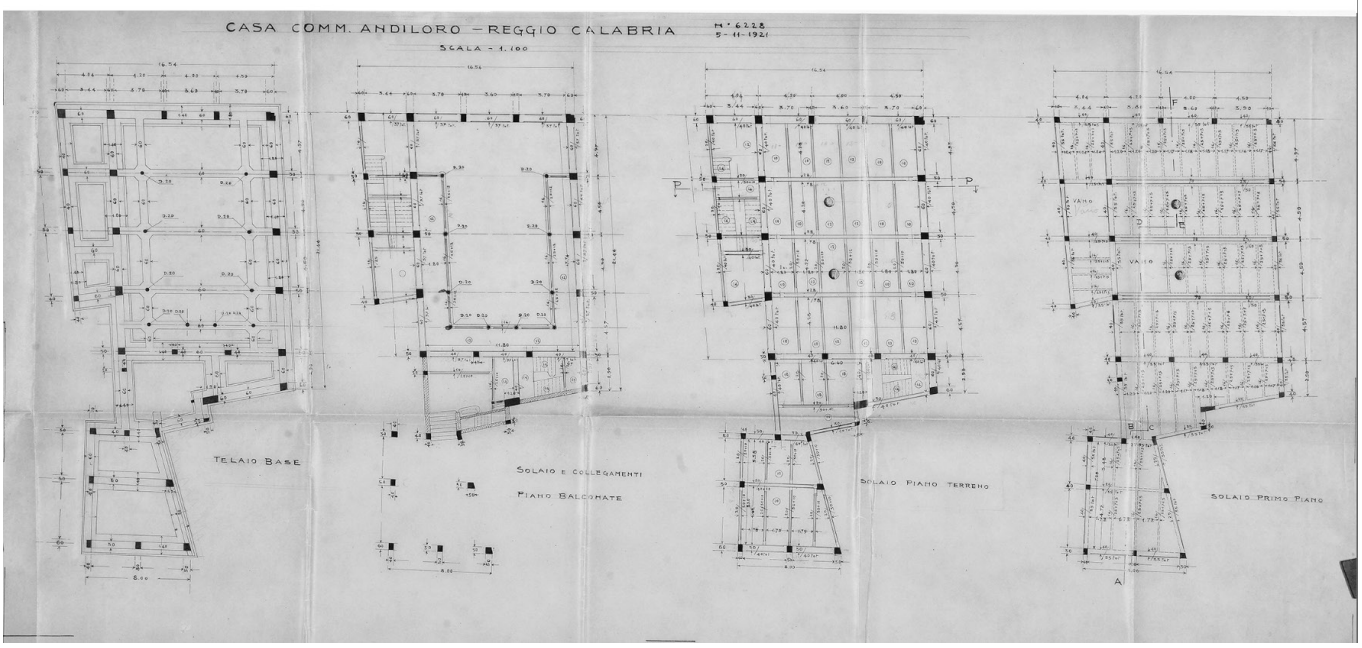


that outline their architectural individuality recall each other by composing a harmonized system of urban backdrops for streets, widenings and squares in the city center suitable to celebrate the nuova Reggio [5].The intent to support the prestige of the institutions hosted, qualifying the rank of representation, is also perfectly legible in the drawings dedicated to the functional-distributive system that is expressed through planimetric-spatial articulations typologically defined. These solutions are kept within a grid of alternatives characterized by geometric alignments and modular recurrences that are attentive to the needs of structural design, regulated by mandatory anti-seismic requirements, and interested in rationalizing the construction process to speed up phases and times of the impressive reconstruction work. The architectural details and the elements of finishing and decoration, described in their overall dimensions and represented with skill and precision also in the drawings of the overall, help to inform those responsible for structural calculations, confirming the close collaboration required between the architectural concept conceived and the related technological solutions. The selection of the drawings made to illustrate through images some of the considerations expressed started from an examination of one of the last cadastral maps drawn up before 1908: Centro urbano di Reggio Calabria which shows the situation of the building at 1875 updated to 1878 and 1899. The architectural drawings, including the distribution system, (cover figure; figs. 2, 3) are original copies received from the company, geometric-dimensional bases necessary to define the structural frame system.
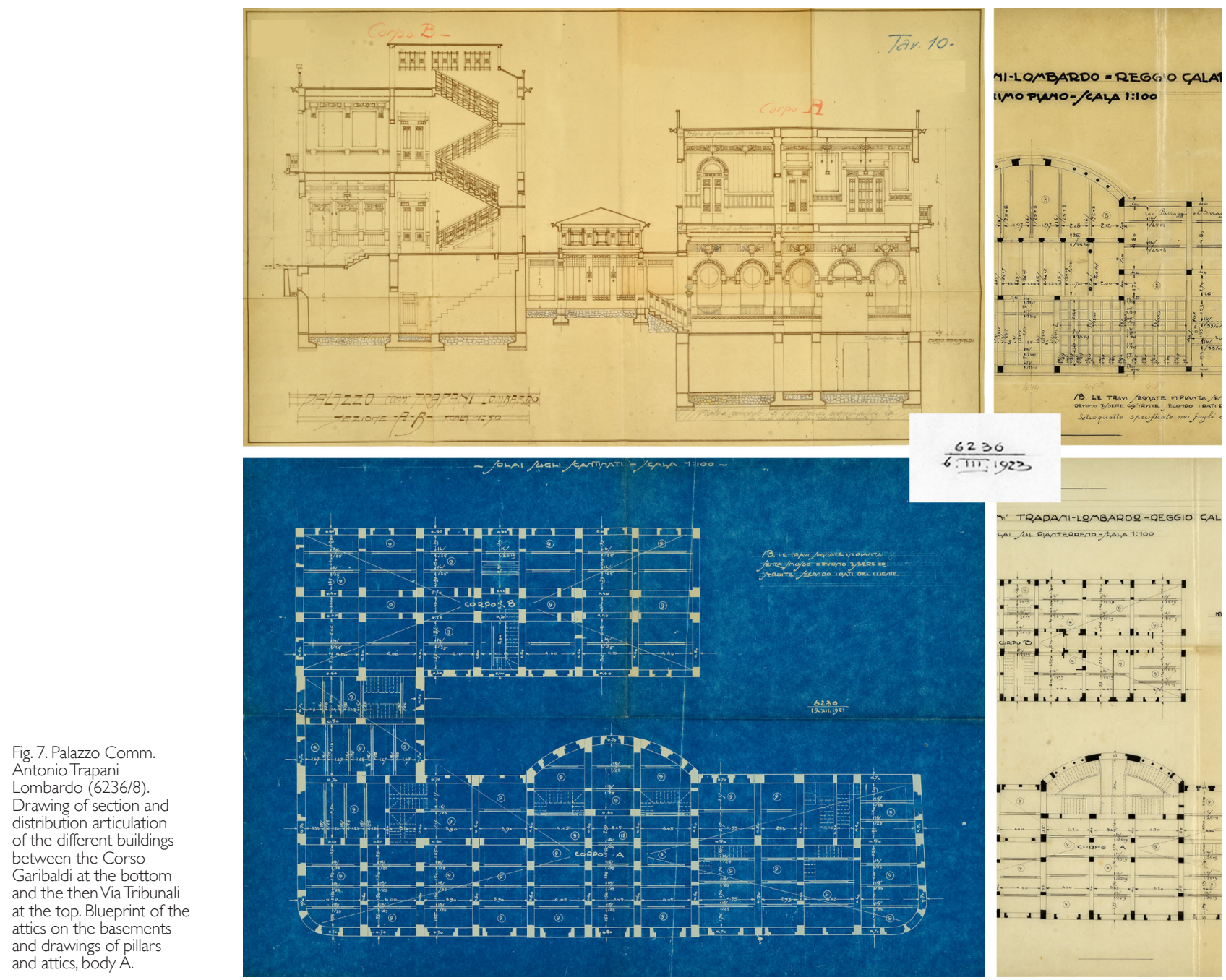


\section{Within the physicality of appearances a warp of resistant armor}

The documents resulting from the calculation and prepared for the construction execution corroborate this vision of desired integration between compositional practice and new technological experimentation: in the living body of the building organism irons and brackets reinforce the concrete membranes and, invisibly, support from the foundations to the roof masses and volumes of the buildings to respond to loads and stresses (fig. 4). These are the evident result of the renewal carried out by engineering applications in the field of structural design and the result of the safety imperatives pursued by ministerial administrations and local special offices, provisions considered suitable to comply with the legislative obligations issued for post-seismic reconstruction, to be resilient, one would say today, in view of possible new calamitous events. The drawings become recurrent traces contained within elaborations of different degrees of definition: sometimes they are simple sketches written to describe the layout of the pillars and floors adopted for the calculations, other times polychrome backgrounds colour the architectural matrix bases to define the schemes of the pillars (or horizons) noting the different geometric and dimensional typologies, other times they are very detailed drawings drawn up to clarify complex or unusual solutions to be transmitted for the correct execution of the works (figs. 5, 9).

In the calculation reports the issues are refined by conforming more and more detailed solutions that are reflected in formalisations that the graphic tables record through details at different scales. In the most complex cases, the symbolic notations are replaced by more communicative iconographic drafts, useful for bureaucratic verifications and for operational indications addressed to the workers. (figs. 4, 6).
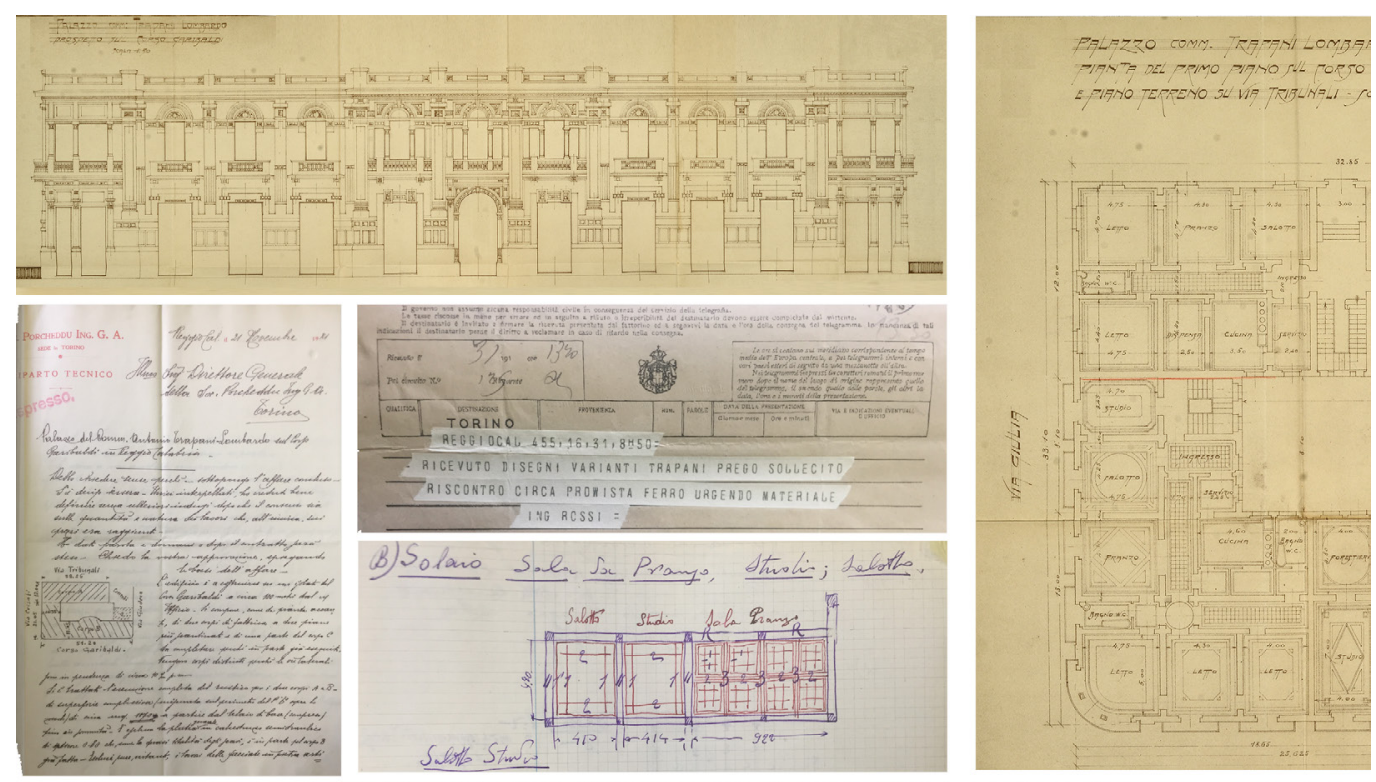

Fig. 8. Palazzo

Trapani Lombardo: al centro, documenti sull'impostazio
planimetrica,

planimetrica,
corrispondenza e stralcio di variante a cassetton richiesta dal cliente per il solaio della parte centrale del primo piano. Architettonici generali e particolare di pianta con evidenziate le destinazioni d'uso dei vani.
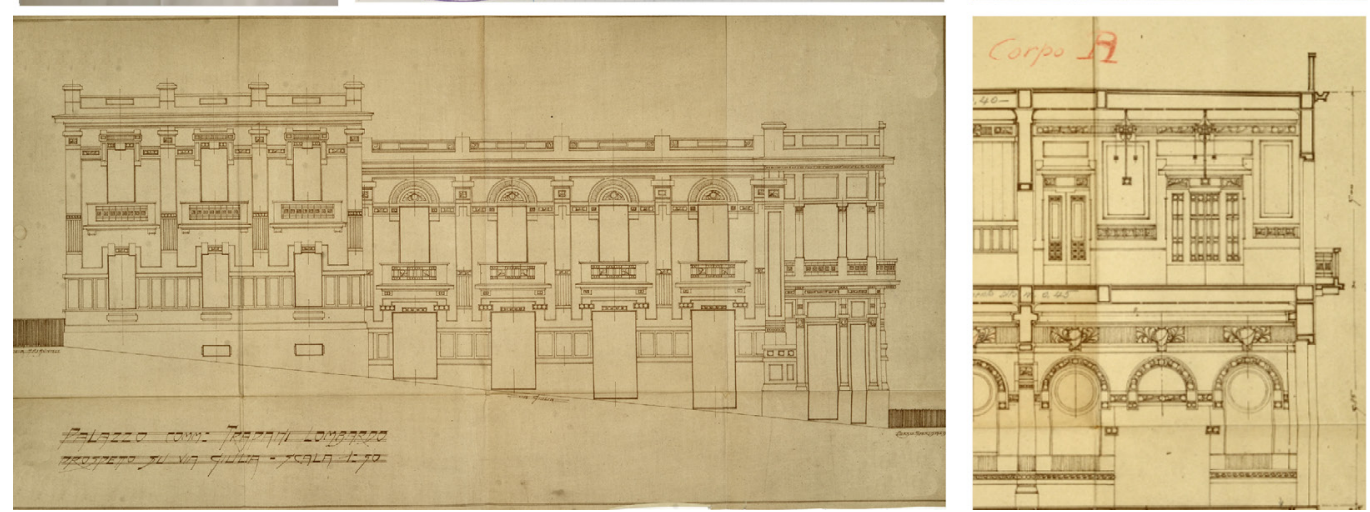
In order to correctly perform its cognitive function, the representation must break down the process into a series of simplified subsystems directed by distinct objectives, introduce specialized filters, invent linguistic syntaxes and new lexicons to guarantee the information links necessary for a correct recomposition of the system as a whole.

A compendium of examples seemed to be an effective means of corroborating the reflections expressed. In the collected synthesis the spatial articulation of the framed system of general level is compared with the following levels of detail. The excerpts are taken from some practices considered more significant, among these there remains a trace of some works that record a private client two cases that are interesting because they allow to point out how the operational practice of the company appears to be consolidated (figs. $7,8)$, and follows the same rigorous canons of editorial care adopted for the interventions of greater complexity [6].

\section{Concluding note, almost a confession}

I tried to synthesize, but I missed a lot. Personal and family memories kept them hidden by the rightful modesty that hides intimate things, and yet they hover in the places they pass through and subtly intertwine with the scientific interests that I tried to condense into reflections to be shared or questioned. During the itinerary I walked, not only metaphorically, frequented roads to open scenarios on the drawing, to connect and reduce the apparent distances between its various expressions, I hope I succeeded.

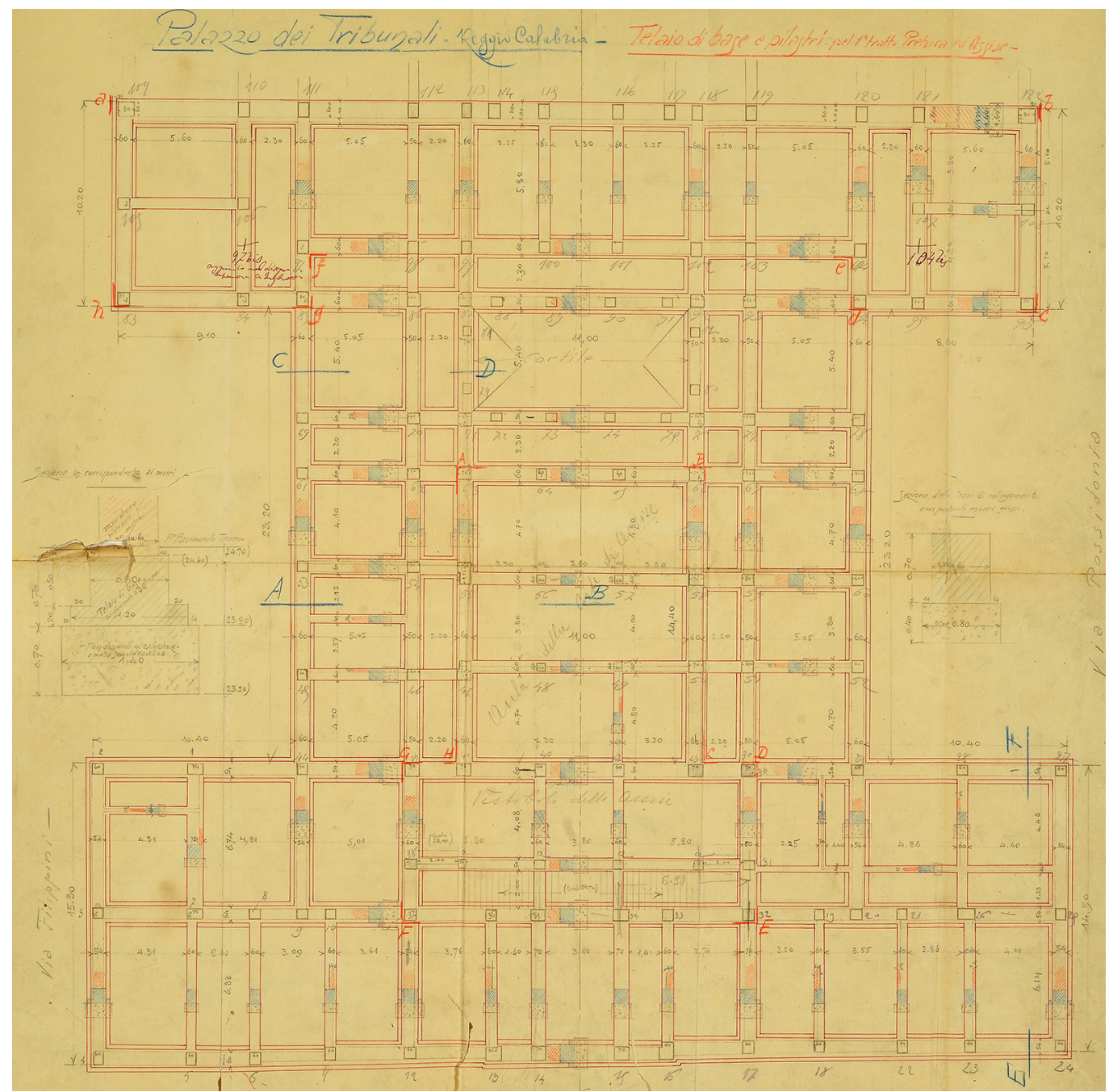




\section{Notes}

[I] To illustrate the importance of the Società Porcheddu, its significant contribution to the diffusion of the technology of reinforced concrete structures, of the Hennebique system-brevetto system and of the cultural and technical context within which the company operated, we point out the volumes of Nelva Riccardo, Signorelli Bruno, 1990 and lori Tullia, with A. Marzo Magno, 2011 .

[2] Nelva-Signorelli, op.cit:: "The archive is ordered by location and by years. The files are dated from 1895 to 1933 (with the exception of some works that do not use the AC, prior to 1895). It is divided into the following localities or zones: Turin (I 02): Piedmont (70): Milan-Lombardy (26); Rome ( 19); Veneto (I I); Liguria (58); Genoa (62); Messina Palermo (I I); Reggio Calabria (8); Sardinia (3); Tripoli (2); various zones ( I3)". File number in brackets. Today the historical heritage is kept at the Department of Structural, Building and Geotechnics Engineering of the Politecnico di Torino.

[3]Together with Law no. 8 and no. 12 of 12/01/1909, concerning Measures and provisions following the earthquake of 28/1 2/1908, and Royal Decree no. 193 of I 8/04/1909, on I 3/07/1910 no. 466 and 28/07/19 I I no. 482, the provisions for the construction of public government buildings came into force.

[4] Engineer, appointed by the mayorValentino to draw up the new Master Plan of the city of Reggio Calabria approved in 191। in 1914 he held the position of municipal councillor for public works; although his Plan had as reference the Mori Plan of I 785, drawn up after the earthquake of 1783, and the enlargement plans of 1868 and 1898 , the introduction of a series of squares, widenings and green areas within the chessboard of blocks is the urban design of a renewed vision that has characterized the urban landscape of Reggio Calabria for a long time.

[5] I recommend the interesting book by Daniele Colistra, with a presentation by Massimo Giovannini, published in 1999 on the urban morphology and architecture of Reggio, to which I refer for further information on the culture of the project of those years.

[6] Palazzo del Comm. Trapani Lombardo and Cinematografo in casa del Comm. Andiloro, interventions started in 1921, on Corso Garibaldi.

\section{Riferimenti bibliografici}

Colistra Daniele (1999). Reggio Calabria L’Architettura e la Città. Reggio Calabria: Jason Editrice.

Gabetti Roberto (1955). Origini del calcestruzzo armato, parte / e II.Torino: Edizioni Rata.

Iori Tullia (200 I). II cemento armato in Italia dalle origini alla seconda guerra mondiale. Roma: Edilstampa.

Iori Tullia, Marzo Magno Alessandro (20I I). I 50 anni di storia del cemento in Italia. Le opere, gli uomini, le imprese. Roma: Gangemi Editore.

Nelva Riccardo, Signorelli Bruno (1990). Avvento ed evoluzione del calcestruzzo in Italia: il sistema Hennebique. Milano: Edizioni di scienza e tecnica.

Novello Giuseppa, Bocconcino Maurizio, Vincenzo Donato (2017). Sperimentalismo grafico e invarianze di metodi nel disegno del cemento armato agli inizi del 1900: l'innovazione esige adattamento e invenzione di codici. In di Luggo Antonella et al. (a cura di). Territori e frontiere della rappresentazione. Atti del $39^{\circ}$ Convegno Internazionale dei Docenti delle Discipline della Rappresentazione. Napoli, I4- 16 settembre 2017, pp. 859-862. Roma: Gangemi.

Novello Giuseppa, Bocconcino Maurizio Marco (2018). Archivi vivendi: nuove alleanze tra beni conservati, forme di rappresentazione e metodi di diffusione del patrimonio tecnico. In Minutoli Fabio (a cura di). L'intreccio dei saperi per rispettare il passato, interpretare il presente, salvaguardare il futuro, Atti VI Convegno Internazionale REUSO 2018 Documentazione, conservazione e recupero del patrimonio architettonico e sulla tutela paesaggistica. Messina, I I- I 3 ottobre 20 I 8, pp. 2603-26 I4. Roma: Gangemi Editore.

Andavamo al cinema: <https://filmscoop.org/category/vecchie-sale-cinematografiche-italiane>.

Author

Giuseppa Novello, Politecnico di Torino, pina.novello@polito.it

To cite this chapter: Novello Giuseppa (2020). Memorie tecniche e ricordi familiari.Torino e Reggio Calabria nelle carte e nei disegni dell'archivio Porcheddu/Technical memories and familiar remembering. Torino and Reggio Calabria in the papers and in the drawings of the Porcheddu Archive. In Arena A., Arena M., Brandolino R.G., Colistra D., Ginex G., Mediati D., Nucifora S., Raffa P. (a cura di). Connettere. Un disegno per annodare e tessere. Atti del $42^{\circ}$ Convegno Internazionale dei Docenti delle Discipline della Rappresentazione/Connecting. Drawing for weaving relationships. Proceedings of the 42 th International Conference of Representation Disciplines Teachers. Milano: FrancoAngeli, pp. 680-703. 